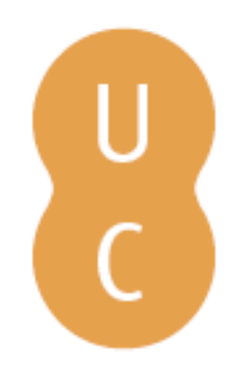

\title{
pompalina
}

Portugal de lés a lés: os itinerários nos livros de viagens britânicos entre 1950 e 2000

Autor(es): $\quad$ Alves, Valentino; Gomes, Rui

Publicado por: Imprensa da Universidade de Coimbra

URL persistente:

URI:http://hdl.handle.net/10316.2/37372

DOI:

DOI:http://dx.doi.org/10.14195/978-989-26-0754-2_8

Accessed : $\quad$ 26-Apr-2023 11:55:34

A navegação consulta e descarregamento dos títulos inseridos nas Bibliotecas Digitais UC Digitalis, UC Pombalina e UC Impactum, pressupõem a aceitação plena e sem reservas dos Termos e Condições de Uso destas Bibliotecas Digitais, disponíveis em https://digitalis.uc.pt/pt-pt/termos.

Conforme exposto nos referidos Termos e Condições de Uso, o descarregamento de títulos de acesso restrito requer uma licença válida de autorização devendo o utilizador aceder ao(s) documento(s) a partir de um endereço de IP da instituição detentora da supramencionada licença.

Ao utilizador é apenas permitido o descarregamento para uso pessoal, pelo que o emprego do(s) título(s) descarregado(s) para outro fim, designadamente comercial, carece de autorização do respetivo autor ou editor da obra.

Na medida em que todas as obras da UC Digitalis se encontram protegidas pelo Código do Direito de Autor e Direitos Conexos e demais legislação aplicável, toda a cópia, parcial ou total, deste documento, nos casos em que é legalmente admitida, deverá conter ou fazer-se acompanhar por este aviso. 
VALENTINO ALVES, RUI GOMES

Universidade de Coimbra

\section{PORTUGAL DE LÉSA Lés: OS ITINERÁrios NOS LIVROS DE VIAGENS BRITÂNICOS ENTRE 1950 E 2000}

\section{Introdução}

O turismo pode ser entendido como um fenómeno social multidimensional onde os livros de viagens têm um papel fundamental na estruturação da experiência turística, funcionando como mediadores entre a identidade do local e a representação de determinado espaço turístico.

Utilizando como fonte os livros de viagens britânicos editados na $2 .^{\mathrm{a}}$ metade do século XX, o presente artigo analisa os itinerários propostos no intuito de traçar um quadro que auxilie na construção de uma representação da viagem em território nacional.

Os principais resultados desta investigação prendem-se com a demarcação territorial dos principais eixos e núcleos turísticos que sobressaem dos itinerários analisados e com a reflexão em torno da interpenetração entre os discursos turísticos e políticos.

\section{A viagem: Os Itinerários}

No âmbito do estudo dos livros de viagens emerge a importância de conhecer e pensar os itinerários físicos e imaginários que os autores propõem, uma vez que estes constituem verdadeiros contextos. Na nossa análise, embora uma parte substancial dos itinerários propostos pelos 
livros de viagens possam ser, de fato, transcritos para a materialidade de um mapa com um grau de certeza apreciável, porque o autor refere exatamente a estrada ou a direção e o tipo de caminhos seguidos, a duração da viagem ou a localidade onde pernoitou; por vezes, apenas a partir do seguimento lógico das atrações e localidades referenciadas se consegue traçar uma rota previsível. De qualquer forma, apesar de esta tarefa se revelar complexa, pela existência de múltiplas e subjetivas variáveis em jogo, a sua exequibilidade não é, em nossa opinião, comprometida.

Porém, nalguns livros, sobretudo aqueles que mais se aproximam do guia, a estruturação da viagem segue por caminhos onde a ordenação temática ou alfabética surgem como fios condutores. Neste ponto, tivemos que utilizar as ferramentas interpretativas e lógicas de modo a dar sentido físico à viagem escrita.

Assim, a partir da avaliação dos rumos e ritmos de viagem podemos depreender quais as zonas do país a que o autor dá mais importância; quais as localidades que funcionam como centros nevrálgicos e quais se destinam a ser pontos de passagem ou de início ou fim de trajeto e que relação de complementaridade se forma entre as diversas localidades.

Por outro lado, saber quais os meios de transporte utilizados nas viagens contribui para o aprofundamento do conhecimento da experiência turística. Nesta perspetiva, viajar de carro, de transportes públicos ou a pé, para além das distintas sensações que provocam nos sujeitos, condicionam de modo desigual a apreensão da realidade. Assim, embora na maior parte dos livros de viagens não se conheçam todos os passos e como foram dados, parece-nos pertinente conhecer, tanto quanto possível, o modo de deslocação mais utilizado pelo autor-viajante.

De fato, as viagens propostas pelos livros de viagens têm muitos inícios e outros tantos fins, os traçados que cunham nos mapas deixam uma marca real nos territórios e nos leitores-viajantes. O itinerário é, por este prisma, uma forma de hierarquizar o território, definindo os caminhos dos turistas e os caminhos dos outros. 


\section{The Selective Traveller in Portugal (1958) de Ann Bridge e Susan Lowndes}

Ann Bridge e Susan Lowndes percorreram num pequeno carro "as zonas mais remotas do país (...) em busca de locais raramente visitados por estrangeiros, tomando notas, tirando fotografias, analisando e verificando o que outros antes delas já haviam escrito." (Pinho, 2009: 107 e 108).

Os itinerários que as duas autoras propõem, demonstram a sua determinação em cobrir turisticamente uma parte substancial de Portugal.

Lisboa assume-se como a mais importante localidade turística, quer pelo fato de ser a primeira a ser visitada e ser o centro dos itinerários propostos, quer porque é uma das duas cidades (a outra é Évora) que justifica um capítulo. De resto, como se pode verificar no Mapa 1, Lisboa e os seus arredores ocupam 3 dos 13 capítulos do livro.

Depois de esmiuçada a capital, The Selective Traveller (1958) atravessa o Tejo e a partir de Cacilhas visita a Península de Setúbal, dirigindo-se para o interior alentejano, passando por Évora e, continuando em direção à fronteira, sobe até Portalegre, acabando este périplo na remota vila de Aviz.

A pouca importância dada às zonas mais a sul do país está patente na etapa que leva o turista desde Alcácer do Sal até Sines, passando por todo o litoral algarvio. O Algarve ainda não é, neste livro, merecedor de ser, a par de Lisboa, o cartão-de-visita do turismo de Portugal.

A oitava etapa, designada de Estremadura, leva o viajante de Óbidos a Santarém; daqui partirá rumo à Beira Baixa e Serra da Estrela, terminando este segmento da viagem em Castelo Branco. De seguida, Coimbra e o Mondego afirmam-se como figuras centrais de um itinerário que se iniciará naquela cidade e terminará em Viseu.

O norte de Portugal foi coberto em três etapas: a primeira entre Aveiro e Porto; a segunda entre Lamego e Montalegre; e a terceira entre Santo Tirso e Monção.

A partir da análise do traçado de viagem de Bridge e Lowndes verificamos que: 
a) As capitais de distrito assumem grande importância na estruturação dos itinerários, uma vez que se distinguem por serem, amiúde, o início ou o fim dos mesmos;

b) As principais praias nacionais já são identificadas como pontos de passagem, mas é a sul da Figueira da Foz que se verifica a maior oferta de localidades costeiras de interesse turístico;

c) As regiões mais interiores apresentam uma considerável importância na oferta turística nacional;

d) Como já referimos, Lisboa é a localidade mais apreciada, afirmando-se como a capital turística do país.

\section{Portuguese Journey (1954) de Garry Hogg}

O livro de Garry Hogg, por seguir a viagem real realizada pelo autor apresenta itinerários fluidos onde as localidades assumem, simultaneamente, o papel terminal e inaugural dos trajetos. O autor, na companhia da sua mulher, viaja a pé, em transportes públicos e através de boleias.

Como se pode verificar no Mapa 2, as primeiras 3 etapas do seu percurso levam Gary Hogg a conhecer a região a sudoeste de Lisboa. Partindo da capital, passa por Setúbal e segue para Sagres pela Costa Alentejana; depois, sempre junto ao litoral, desloca-se até Olhão, fletindo, finalmente, para norte, cruzando parte do Alentejo até regressar a Lisboa.

De Lisboa ruma para a Batalha e, viajando pelo interior, inicia uma longa jornada que o fará passar por Fátima, Castelo Branco e Guarda, terminando este segmento em Coimbra. Daqui seguirá o percurso do Rio Mondego até ao litoral e continuando para norte passará por Aveiro, Porto, Viana do Castelo e, finalmente, Caminha. Desta cidade minhota seguirá para Braga, Guimarães, Vila Real e Bragança, terminando a sua visita a Portugal em Chaves.

O trajeto da viagem seguido em Portuguese Journey (1954) mostra uma rota linear, onde a hierarquização do território é maior, uma vez que ignora uma parte substancial do país. Por outro lado, e devido a esse 
fato, aponta mais concretamente o que pode ser considerado essencial e acessório no Portugal turístico da década de 50.

Assim, o trajeto de Hogg demonstra que:

a) Lisboa volta a ser o centro nevrálgico das operações, ponto inicial da viagem e base para as visitas ao sul e centro do país (de resto, este autor reflete uma tendência, patente em alguns livros de viagens, de iniciar as visitas ao país a partir da capital, rumar ao Sul e só mais tarde dirigir-se para o norte de Portugal);

b) O Algarve turístico é explorado desde o barlavento até Olhão;

c) O litoral norte é preferido em relação ao interior do país;

d) O interior do Minho e Trás-os-Montes, bem como a Serra da Estrela (ex-libris dos ambientes de montanha), justificam uma incursão no âmago de Portugal;

e) As capitais de distrito assumem-se como pontos importantes da oferta turística (sendo, no entanto, de destacar a ausência de Évora neste itinerário).

\section{Your Holiday in Spain and Portugal (1952) de Gordon Cooper}

O livro de Gordon Cooper, por incluir Espanha e Portugal, apresenta uma versão condensada do nosso país e fruto da hierarquização do território ajuda-nos a conhecer as suas zonas turísticas essenciais.

A viagem de Your Holiday in Spain and Portugal (1952), como se pode verificar no Mapa 3, inicia-se em Lisboa, rumando, de seguida, para Mafra, passando por Coimbra e culminando no Buçaco. Depois, a partir do Porto, propõe dois trajetos, a sul passando por Aveiro e Viseu; e a norte, passando por Guimarães, Braga e Viana do Castelo.

A sul de Lisboa destaca-se um itinerário baseado em Évora e Vila Viçosa e a costa algarvia que seria visitada entre Lagos e Olhão.

A leitura dos itinerários propostos por Cooper ao seu leitor demonstra que: 
a) Lisboa continua a ser o local natural para iniciar uma viagem por Portugal;

b) As zonas costeiras (à exceção, sobretudo, da costa algarvia) não são um especial ponto de atração quando a visita a Portugal é limitada;

c) O interior do país é esquecido neste mapa turístico (assinala-se, no entanto, a existência de um pequeno itinerário baseado em Évora);

d) A cidade do Porto funciona como base de apoio a deslocações no norte de Portugal;

e) A zona mais oriental do Algarve continua a ser pouco relevante do ponto de vista turístico.

\section{Portuguese Journey (1963) de Wilfred Theodore Blake}

A viagem de Blake por Portugal, efetuada de automóvel, apresenta duas interessantes caraterísticas: a primeira reside no fato de a viagem se iniciar a partir do norte de Portugal, mais precisamente Caminha, uma vez que alguns turistas britânicos optavam por fazer a viagem de barco até à Galiza, trazendo consigo os seus automóveis; a segunda reside no fato de a sua rota contemplar uma ida a Espanha.

Como se pode ver no Mapa 4, a rota proposta por Portuguese Journey (1963) inicia-se em Caminha e, seguindo pelo litoral, passa por Viana do Castelo e Porto. Depois, a partir de Vila Nova de Gaia, dirige-se diretamente para Coimbra, com um ligeiro desvio para visitar o Buçaco. De seguida, e após um novo desvio até à Figueira da Foz, o itinerário segue, através da Estrada Nacional n. ${ }^{\circ}$, até Leiria, passando, de seguida, pelas localidades turísticas habitualmente mais visitadas até atingir Lisboa.

De Lisboa, atravessando em Cacilhas, o nosso autor segue por Setúbal e depois, sempre próximo da costa, atinge o barlavento algarvio, percorrendo o litoral até Vila Real de Santo António.

Após uma incursão por Espanha, volta a entrar em território nacional próximo de Serpa, e, dirigindo-se para norte, atravessa Beja e Évora. Seguindo sempre pelo interior do país, sem no entanto entrar na zona mais montanhosa, volta a tocar Coimbra no seu trajeto ascendente, que 
em Vila Real sofrerá uma bifurcação, primeiro com uma volta por Trás-os-Montes e depois rumo a Guimarães e Braga, logrando sair do país por onde entrara.

A viagem de W. T. Blake mostra-nos que:

a) Além da natural entrada em Portugal através de Lisboa, a cidade de Caminha apresentava-se como uma porta utilizada pelos cidadãos britânicos que viajavam de barco até à Península Ibérica;

b) As zonas costeiras (excetuando, sobretudo, a costa algarvia) continuavam a não ser locais de especial interesse para os viajantes britânicos; todavia, os desvios para visitar a Figueira da Foz, Nazaré e Sines, demonstram a importância destas localidades;

c) Apesar de a viagem não se iniciar em Lisboa, e da capital não merecer aqui o relevo de outras obras, assinala-se o fato de a passagem para o sul se efetuar, também neste relato, através de Cacilhas;

d) O litoral algarvio é visitado em toda a sua extensão;

e) Existe uma complementaridade turística entre Portugal e Espanha, visível na passagem de Blake pelo nosso país vizinho;

f) Não obstante o seu itinerário contemplar várias regiões do interior de Portugal (sendo de destacar o grande desvio para visitar Trás-os-Montes), a Serra da Estrela e zonas envolventes são esquecidas.

\section{Fortnight in Portugal (1964) de Cedric Salter}

O livro de Cedric Salter é dedicado aos turistas que se instalam durante duas semanas ${ }^{1}$ numa determinada zona do país e que, a partir dessa base central, exploram as regiões limítrofes. O autor defende a ideia de férias repartidas entre tempos de descanso, como os passados à beira-mar, e tempos de atividade, como passeios e visitas culturais.

Assim, observando o Mapa 5, verificamos que o autor retoma Lisboa como o ponto inicial da viagem, quer para uma pequena deslocação pelos arredores

${ }^{1}$ Fortnight é a unidade de tempo equivalente a 14 dias. A palavra deriva do inglês arcaico feorwertyne nibt que significa fourteen nights. 
a Norte e a Sul, quer para uma tirada maior até ao Buçaco, com as passagens mais ou menos habituais por Óbidos, Alcobaça, Batalha, Fátima e Coimbra. O mesmo esquema é utilizado com o Porto, onde a cidade é utilizada como base logística para as visitas ao Sul até Aveiro e a Norte ao Minho.

Também no Algarve se delineia um itinerário semelhante, onde a Praia da Rocha funciona como fulcro para o conhecimento dessa província.

É ainda digno de realce o fato de o autor sugerir visitas isoladas a determinados pontos do país, casos de Beja, Évora, Santarém e Tomar.

Os itinerários propostos em A fortnight in Portugal (1964) demonstram que:

a) A oferta turística nacional assenta em três núcleos fundamentais: Lisboa, Porto e Algarve;

b) Os ambientes costeiros ganham predominância turística e o interior de Portugal é praticamente esquecido;

c) Realça-se a introdução do conceito de estada fixa complementada por deslocações curtas;

d) Os locais mais distantes dos principais centros turísticos tendem a perder importância devido à deslocação mais prolongada que exigem.

\section{Your guide to Portugal (1965) de Douglas Clyne}

A obra de Douglas Clyne é um guia dedicado ao turista britânico que utiliza o automóvel para a realização da sua viagem. O autor chega a Portugal através de Trás-os-Montes, depois de cruzar o território espanhol. Por ser um livro dedicado ao motorista, o seu conteúdo fornece múltiplas (e precisas) indicações rodoviárias, sem no entanto apontar um itinerário linear.

Ao analisarmos o Mapa 6, verificamos que o autor desenrola os seus itinerários no sentido Norte-Sul, segue as delimitações geográficas das províncias para dar sentido aos trajetos e cobre exaustivamente grande parte de Portugal. O resultado é um mapa demasiado preenchido e que, por fornecer demasiadas alternativas, acaba por não ser de fácil leitura e exequibilidade, fazendo com que determinadas localidades surjam em 
mais do que um itinerário, demonstrando claramente que o leitor-viajante teria que escolher o seu caminho a partir da teia proposta pelo autor.

Pelo exposto, mais do que descrever sucintamente os itinerários, as propostas de Douglas Clyne merecem uma leitura atenta, uma vez que:

a) Organizam o território nacional a partir de centros turísticos e logísticos, de onde se destacam Bragança, Braga, Porto, Coimbra, Leiria, Castelo Branco e Lisboa;

b) Realçam a importância turística de Portugal como um todo, embora se verifique um cuidado especial com o litoral da Costa Verde, do sul da Costa de Prata, Costa de Lisboa e Algarve;

c) Demonstram a maior profusão de localidades turísticas a norte de Lisboa;

d) Destacam a complementaridade turística entre Portugal e Espanha.

\section{Portugal, Letts Holiday Guides (1972) de Ted Appleton, Gwen Fer- guson, e outros}

Portugal, Letts Holiday Guides (1972) é um pequeno guia que se esforça por sintetizar toda a informação pertinente para o turista. Este objetivo de condensação é também visível na limitação dos itinerários propostos, numa clara alusão à falta de disponibilidade que o leitor-turista terá para conhecer Portugal em profundidade.

Assim, este livro propõe 4 itinerários (ver Mapa 7), sendo os primeiros com base em Lisboa; um rumo ao Sul até Évora, e outro em direção ao Norte até Aveiro. O terceiro percurso leva o turista a conhecer o Algarve de Este para Oeste, ou seja, de Vila Real de Santo António a Sagres. O último itinerário propõe uma pequena volta pelo Minho, com início no Porto, passando por Guimarães e Braga e terminando em Viana do Castelo.

Da análise dos itinerários propostos por este livro, realçamos o seguinte:

a) A concentração do Portugal turístico em zonas limitadas do território: Algarve, Eixo Lisboa-Aveiro, Lisboa-Évora e Porto-Viana do Castelo; 
b) Valorização da vertente atlântica do país, levando à exclusão de quase todo o interior, como, por exemplo, os distritos de Viseu, Vila Real ou Bragança;

c) Sobressai a importância de Lisboa (cidade central e ponto inicial de 2 dos 4 itinerários) e do Algarve.

\section{Portugal (1970) de Cedric Salter}

O livro Portugal (1970) de Cedric Salter apresenta uma variedade de itinerários que embora não cubra detalhadamente o país, consegue representar parte da pluralidade turística de Portugal.

A viagem, como se pode verificar no Mapa 8, é estruturada em 6 itinerários, sendo que 3 deles principiam em Lisboa: o primeiro leva o turista pelos arredores da capital até Mafra; o segundo cobre uma parte importante do Alentejo e termina em Castelo de Vide; e o terceiro, de grande extensão, leva o turista até Bragança, passando por Santarém, Castelo Branco, Manteigas, Viseu, Aveiro, Minho e Trás-os-Montes.

Um outro itinerário mostra as Terras do Centro: com início em Coimbra, segue linearmente até Peniche, não obstante as habituais deambulações por outras localidades turísticas, como a Figueira da Foz, Nazaré, Fátima e Tomar. A cidade do Porto é, neste livro, alvo de especial interesse e justifica um itinerário.

Finalmente, o Algarve também é percorrido com algum detalhe (sobretudo a zona costeira), com o itinerário a iniciar-se em Castro Marim e a terminar no Cabo de S. Vicente.

Da análise da viagem de Cedric Salter salienta-se o seguinte:

a) Importância de Lisboa (ponto inicial de dois itinerários), do Porto (justifica um itinerário) e de Coimbra (local inicial de um itinerário);

b) Preocupação do autor em apresentar uma parte importante do país, não esquecendo o interior, se bem que a tirada entre Lisboa e Bragança seja, notoriamente, algo forçada, pela sua extensão;

c) Afirmação da importância do Algarve que, mais uma vez, é percorrido em toda a sua totalidade. 


\section{Portugal (1972) de Henry Myhill}

Deslocando-se numa auto-caravana, Henry Myhill encetou uma longa viagem por Portugal em busca dos principais pontos de atração. Profundo conhecedor do nosso país, apresentou ao seu leitor um território diversificado, embora, na realidade, os seus itinerários não se distingam grandemente dos propostos por outros livros de viagens.

De resto, como podemos verificar no Mapa 9, os seus 13 itinerários cobriram o que de mais importante, do ponto de vista turístico, o país tinha para oferecer. As suas rotas isolam partes importantes da oferta turística nacional, como o Minho, Trás-os-Montes, Douro, Alentejo, Mondego, Serra da Estrela, Setúbal e Algarve.

Os itinerários do livro de Myhill revelam que:

a) Lisboa assume uma posição altaneira, quer por merecer uma visita detalhada, quer por ser o ponto inicial para conhecer toda a zona entre Santarém e Leiria;

b) Coimbra, Cidade Amada, também é alvo de uma aturada visita e ponto inicial de um itinerário;

c) O Algarve não é tão detalhadamente visitado como por outros autores e Faro assume a posição central na região;

d) O curso do Rio Douro, e a temática do Vinho do Porto, justificam um itinerário que principia em Vila Nova de Gaia e termina em Lamego;

e) Embora as zonas mais litorais representem a maioria dos pontos turísticos, o interior com seus cenários diversificados, como, por exemplo, a montanha e o rural, também é salientado.

\section{Traveller's Portugal (1987) de Anthony Hogg}

Hogg dirige a sua obra a turistas que percorrerão o país de carro e que se afastarão da habitual permanência junto à costa. Adicionalmente, sabemos que alguns dos itinerários que propõe foram realizados pelo autor num pequeno Mini. 
Os itinerários propostos neste livro de viagens são, como se pode verificar pela leitura do Mapa 10, caraterizados, no interior do território nacional, pela sua relativa pequena extensão, o que reforça a sua exequibilidade e complementaridade entre as localidades portuguesas e espanholas. A viagem segue, em traços gerais, o sentido Norte-Sul e os itinerários encontram-se organizados tematicamente e espacialmente, embora raramente os pontos de chegada sejam, simultaneamente, locais de partida.

A análise dos itinerários propostos por Anthony Hogg revela que:

a) $\mathrm{O}$ autor planifica a viagem de modo a oferecer uma ampla cobertura de todo o território nacional, privilegiando, no entanto, determinadas zonas nobres de produção vinícola, como o Douro e o Alentejo;

b) Não se verifica uma tendência exacerbada de fazer sobressair as zonas costeiras, aliás, algumas das habituais localidades visitadas são esquecidas nesta obra, como é o caso da Nazaré ou Peniche;

c) Verifica-se uma complementaridade turística entre Portugal e Espanha;

g) O Alentejo é profusamente visitado através de diversos itinerários e o litoral algarvio é visitado em toda a sua extensão;

d) Ao ser o ponto inaugural de 3 itinerários, Lisboa reforça a sua importante posição na oferta turística nacional.

\section{Mean Feat - A 3,000-mile walk through Portugal, Spain, France, Switzerland and Italy (1985) de John Waite}

A rota que John Waite seguiu em Portugal reflete as condicionantes estruturais da sua aventura que o levou numa longa viagem a pé entre Portugal e Itália. Assim, o autor entra em Portugal a bordo de um comboio que o conduzirá entre Vila Real de Santo António e Mexilhoeira Grande, ponto inaugural da sua travessia pedestre do território nacional em 35 dias.

Como se pode verificar no Mapa 11, o autor segue desde o Algarve até à Lousã pelo interior do país e traçando, dentro das possibilidades, uma linha orientada para a redução de espaço a percorrer. Assim, Waite passará por muitas localidades que geralmente se encontram fora dos 
livros de viagens mais turísticos; todavia, nem mesmo este autor resiste aos encantos da ligação histórica entre Portugal e Inglaterra, tão retratada nos livros de viagens, e faz um pequeno desvio na sua viagem para visitar o Buçaco. O trajeto entre a Lousã e o Buçaco e respetivo retorno foi feito em comboio, continuando depois a sua aventura pedestre até Arouca. Aí o autor apanhará boleia até ao Porto onde iniciará o último segmento da sua viagem por Portugal que terminará em Valença.

Os itinerários de Waite, porque elaborados de acordo com objetivos específicos, não nos fornecem muitas pistas relativamente à relação turismo-espaço, no entanto, algumas ilações deverão retirar-se:

a) O fato dos itinerários não se aproximarem do litoral, demonstra o interesse do autor em percorrer espaços caraterizados pelo ruralismo e ambientes de montanha;

b) Ao contornar as grandes cidades portuguesas, Waite revela a sua vontade de conhecer o verdadeiro Portugal que, para o autor, se encontrava nos espaços mais afastados do desenvolvimento;

c) A sua ida ao Buçaco revela a importância daquele local para os viajantes britânicos e, mais concretamente, para os escritores de livros de viagens sobre Portugal.

\section{Portugal, a Travellers' Guide (1987) de Susan Lowndes}

Portugal, a Travellers' Guide (1987), de Susan Lowndes, é um guia de viagens estruturado em torno dos múltiplos itinerários que disponibiliza ao turista e que se organizam em torno de grandes pólos geográficos. A viagem proposta pela autora tem início em Lisboa, passando de seguida pelos arredores e pela Península de Setúbal. Os itinerários 4, 5, e 6 estruturam-se em torno do Algarve e os seguintes cobrem, sequencialmente, o Alentejo, Ribatejo, Beira Baixa e Beira Alta. O último terço da viagem mostra Coimbra e Aveiro, Porto e arredores, o Minho e, finalmente, Bragança.

Como se pode ver no Mapa 12, a autora tem a preocupação de apresentar um conjunto de itinerários que cobre parte substancial da oferta 
turística nacional, embora se verifique uma apetência pelas zonas costeiras, sobretudo a sul da Nazaré e a norte de Espinho.

A análise dos itinerários propostos por Susan Lowndes demonstra que:

a) Lisboa sobressai como ponto inaugural da viagem e centro logístico de exploração de uma extensa porção de Portugal;

b) A autora tentou fornecer ao leitor um conjunto de rotas que possibilitam o contato com cenários e paisagens diferenciadas, verificando-se a sua apetência pelas zonas de montanha e de fronteira;

c) Não obstante a apetência anteriormente referida, o livro, apesar de bastante equilibrado, realça a vertente atlântica do país, onde as localidades costeiras representam o fulcro da oferta turística.

\section{Off the beaten track, Portugal (1992) de Nick Timmons}

O livro de Nick Timmons hierarquiza o território de modo a fazer sobressair as zonas que potencialmente agradam aos viajantes mais aventureiros, construindo uma imagem de Portugal em redor dos espaços menos explorados pelo turismo. Apoiado em 9 itinerários, o autor inicia a sua viagem de Norte para Sul, com 4 itinerários a norte do Douro, 1 a norte do Mondego e outros 4 cobrindo o Alentejo e Algarve.

Observando o mapa 13, verificamos que no primeiro itinerário o autor dispersa a sua atenção pelas zonas costeiras e zonas mais interiores do Minho; no segundo, concentra-se na zona do Porto; no terceiro, segue, grosso modo, parte do percurso do Rio Douro; e no quarto, cobre a região de Trás-os-Montes.

A meio da sua viagem, o percurso que se inicia em Coimbra, segue para o interior até Linhares e, voltando em direção ao litoral, termina na incontornável Serra do Buçaco.

Finalmente o Sul, apresentando dois itinerários complementares, um dedicado exclusivamente a Évora e um segundo que parte desta cidade até Alter do Chão. Timmons termina o seu livro com um itinerário pela costa alentejana e outro pelo Sotavento Algarvio. 
Da análise da viagem proposta em Off the beaten track, Portugal (1992) salienta-se:

a) A preocupação do autor se afastar dos grandes centros turísticos nacionais, distanciando-se, por exemplo, de Lisboa e arredores e parte do Algarve;

b) Apresentação de um conjunto de itinerários equilibrados (se bem que desgarrados) onde se conjuga a costa e o interior; o Norte e o Sul; a praia, a montanha e a planície; o rural e o urbano; a cultura e a aventura;

c) Os itinerários são propostos de acordo com uma consistência geográfica, podendo, num mesmo segmento de viagem, serem apresentadas atrações diversificadas e sem uma aparente ligação temática.

\section{Backwards out in the big world - A voyage into Portugal (1996) de Paul Hyland}

A viagem de Paul Hyland não tem como objetivo fundamental a apresentação de itinerários que sigam uma lógica turística, o autor utiliza a sua deslocação como ferramenta de contato com o povo e com o espaço de modo a pensar o passado, o presente e o futuro de Portugal.

Não obstante tais princípios, como se pode verificar no Mapa 14, os seus itinerários partem da região de Lisboa e, Tejo acima, o autor entranha-se no país, sendo o curso do rio que fornece lógica ao seu deslocamento. A visita a Évora, desagregada deste contexto geográfico, permite ao autor o contato com uma cidade que, em sua opinião, se distingue das demais localidades visitadas.

A análise da sua viagem demonstra que:

a) Lisboa é a localidade portuguesa mais importante, não só enquanto atração turística mas também como museu vivo e cristalização de um passado glorioso, ou seja, a capital surge como resumo de um país;

b) O Rio Tejo confere uma linha de continuidade geográfica à sua viagem; 
c) Évora apresenta-se como uma cidade ímpar e merecedora de uma aturada visita.

\section{Holiday Portugal (1990) de Katie Wood e George McDonald}

O livro de Wood e McDonald é um verdadeiro guia de viagem, refletindo-se tal na organização dos itinerários propostos. A viagem estrutura-se de Norte para Sul em torno de 12 itinerários principais e 2 complementares onde se verifica a preocupação dos autores de cobrir uma parte significativa do país e onde os ambientes costeiros constituem uma parte fundamental da oferta apresentada.

A análise do Mapa 15 demonstra que:

a) Existe a preocupação de organizar os itinerários de acordo com as caraterísticas físicas do território, como por exemplo, Montanhas (do Norte), Planícies Costeiras ou Costa (de Prata);

b) As principais cidades portuguesas e as localidades costeiras estruturam uma parte fundamental da oferta turística;

c) A norte de Lisboa existe um maior número de localidades turísticas e, concomitantemente, de itinerários;

d) Lisboa e o Algarve são as únicas zonas que têm direito a 2 itinerários, confirmando-se, por esta via, a sua importância turística para os viajantes britânicos.

\section{Conclusões}

Os itinerários propostos e/ou seguidos pelos autores dos livros de viagens que analisámos refletem os objetivos gerais que subjazem à sua construção. Por este prisma, as viagens que os autores propõem, para além do seu escopo fundamental que passa pela orientação do leitor/viajante, pressupõem também uma organização hierarquizada dos espaços, com os itinerários a transportar para o campo de visão do turista as localidades e atrações que 
se transformam em objetos de contemplação e de apoio à prática turística (Urry, 2002).

Nesta perspetiva, a análise individual dos itinerários permite construir uma imagem exclusiva que transporta as diversas condicionantes de cada livro, de cada autor e de cada época. Por outro lado, tal imagem, porque singular e aprofundada, não permite uma visão conjuntural e longitudinal da prática turística, nem a perceção das cambiantes organizativas do território e da viagem, que só poderá ser alcançada através de uma análise conjunta e recorrendo à sobreposição dos diversos itinerários.

Assim, em termos globais, os itinerários que apresentámos, e que correspondem a um período de 50 anos, representam tendências turísticas e refletem as modificações do território.

As grandes conclusões que se podem retirar desta análise conjunta são:

a) Existência de uma fraca complementaridade entre a oferta turística de Portugal e Espanha, ou seja, não obstante os livros de viagens serem apenas sobre Portugal ${ }^{2}$, apenas dois livros abordam diretamente essa problemática, propondo visitas aos dois países;

b) O Algarve vai, ao longo da meia centúria de anos em análise, ganhando espaço nos livros de viagens; tal é visível na extensão territorial da região que é analisada e consequente aumento de localidades turísticas referenciadas, bem como no incremento de itinerários dentro e com destino ou princípio na região;

c) O Barlavento Algarvio foi palco privilegiado dos primeiros itinerários (destacando-se, nesta zona, Sagres e a Praia da Rocha); a Este de Faro as incursões eram mais raras e, sobretudo, menos minuciosas;

d) Lisboa surge como a principal cidade do país, ponto inaugural de muitas viagens e itinerários, funcionando como base para a visita a localidades do centro e sul de Portugal ou como localidade turística per si ou acompanhada de localidades limítrofes;

e) As capitais de distrito mantiveram uma relativa estabilidade nos vários itinerários, tanto nos seus pontos iniciais e finais, mas, sobretudo

\footnotetext{
2 À exceção de Your Holiday in Spain and Portugal (1952) de Gordon Cooper.
} 
como pontos de passagem, afirmando-se como importantes pontos para a estruturação da oferta turística;

f) As zonas costeiras foram ganhando importância na estruturação dos itinerários, sendo que as mais referenciadas são a costa algarvia, a região compreendida entre Setúbal e Nazaré e entre Espinho e Vila Praia de Âncora;

g) A zona entre Lisboa e Batalha afirma-se como uma das mais importantes regiões turísticas, apresentando um dos maiores índices de itinerários, sobressaindo localidades como Lisboa, Estoril, Cascais, Sintra, Mafra, Óbidos, Alcobaça, Batalha, Fátima e Tomar, bem como as localidades costeiras vizinhas, com destaque para a Nazaré, Peniche, Santa Cruz e Ericeira;

b) No Alentejo, a cidade de Évora ofusca as demais localidades, tal é a importância que os viajantes lhe dão;

i) Na zona Centro, Coimbra afigura-se como a cidade mais visitada e ponto importante para muitos itinerários; o Buçaco também merece um destaque especial pela notoriedade que goza entre os viajantes britânicos;

j) A Norte salienta-se a cidade do Porto e a linha do Rio Douro pela sua ligação à temática do Vinho do Porto; o Minho, tanto na vertente costeira como nas cidades históricas, sobretudo Braga e Guimarães; e Trás-os-Montes, com destaque especial para Bragança e Chaves, mas também Vidago e Pedras Salgadas.

Embora os itinerários se distingam de acordo com as caraterísticas específicas inerentes a cada um dos livros de viagens (e salvaguardando também as conclusões que anteriormente indicámos), podemos afirmar que existe uma certa constância nos itinerários propostos, e que apontam para a existência de 6 eixos/núcleos principais de viagem: Lisboa-Buçaco, Aveiro-Porto-Minho, Algarve, Douro, Trás-os-Montes e Évora. Estes eixos e núcleos não têm, evidentemente, a mesma importância turística nem são internamente uniformes, uma vez que entre as diversas localidades também existem relações hierárquicas. Por outro lado, esta proposta visível no Mapa 16 representa uma solução de compromisso visando a 
condensação da imensa informação que retirámos dos livros de viagens, mas que todavia tem o poder de permitir distinguir zonas que pelos itinerários apresentados pelos autores ganharam consistência enquanto palco de viagens.

Assim, na esteira de diversas investigações (cf. Young, 2005), a análise que efetuámos aos livros de viagens que compõem o nosso corpus documental confirma a tendencial hibridez estrutural e de conteúdo caraterística deste subtipo de literatura. De resto, no que aos livros de viagens britânicos sobre Portugal diz respeito, a diversificação opera-se mais na forma e na abordagem ao conteúdo do que no conteúdo propriamente dito; ou seja, verifica-se uma heterogeneização de tipologias discursivas e de concetualizações do fenómeno turístico, mas verifica-se, outrossim, uma elevada estabilidade das localidades e atrações turísticas nacionais e da própria imagem geral do país.

No entanto, apesar da relativa cristalização da representação de Portugal, todos os livros de viagens acrescentam e retiram algo à realidade usando o itinerário como ferramenta essencial na construção do paradigma imagético que pretendem veicular. Assim, a hierarquização dos espaços produz-se através da instrumentalização do itinerário que, moldando a viagem, transporta para o campo de visão do turista as localidades e as atrações que, tornados objetos de contemplação, serão consumidos (Urry, 2002).

Por este prisma, os discursos turísticos construídos pelos livros de viagens reinterpretam e transformam o real, contribuindo para a propagação de um conjunto de símbolos e significados construídos e suportados pela indústria turística para usufruto do turista (Jacobs, 2001). Ganha, a este propósito, importância o turista semiótico, que por todo o mundo "are fanning out in search of signs of Frenchness, typical Italian behavior, exemplary Oriental scenes, typical American throughways, traditional English pubs" Culler (1981: 127). Ou seja, os caminhos são trilhados no intuito de descobrir essa miríade de sinais que só o olhar do turista descodifica e contempla.

Pelo exposto, compreende-se a importância do itinerário, verdadeiro suporte físico e mental estruturador da viagem e da experiência que se 
lhe associa, bem como da narrativa e da fusão entre leitor e turista, pois é através do itinerário que o livro de viagens coloca no seu campo de visão os diversos elementos do real. Esta exacerbada importância do itinerário exige cuidado na sua análise, pois, apesar da narrativa representar, naturalmente, tendências turísticas e refletir as modificações do território, na nossa investigação verificámos que o discurso turístico é condicionado e até instrumentalizado, fruto de condicionantes económicas e políticas exteriores ao interesse do leitor-turista.

Em primeiro lugar, e como havia sido relatado por Fussel (1980), comprova-se também no nosso corpus documental a obsessão dos livros de viagens pelo itinerário. Este desejo de submeter o leitor-turista aos caminhos já percorridos pelo autor, insere-se num contexto de controlo absoluto da experiência turística de modo a assegurar a sua agradabilidade. Ou seja, os livros de viagens consideram-se, em parte, uma extensão das agências e dos guias turísticos, transferindo uma porção importante do ónus da responsabilidade da viagem dos ombros dos leitores (Drucker, 2002). Esta especificidade dos livros de viagens da contemporaneidade, inspiração dos guias de Baedeker, reforça o poder dos discursos turísticos, e consequente aceitação pelo público, sendo-lhes reconhecido o rigor na apresentação da realidade. Cada vez mais o turista, numa crescente atitude de passividade inteletual, enterrará a cabeça entre as páginas dos livros de viagens e apenas a levantará para contrastar o narrado com o percebido.

Por este prisma, o itinerário assume-se como parte fundamental de uma representação artificial da realidade, uma vez que assenta tendencialmente em pressupostos turísticos, ignorando parte dos espaços. Mas, mesmo entre os espaços representados convivem, como explicou Knafou (1992), dois lugares; por um lado, o lugar identitário identificado pelo morador local, e, por outro lado, o lugar de consumo turístico, largamente salientado nas páginas dos livros de viagens.

Em síntese, vimos como o itinerário estrutura o livro de viagens e como este controla o leitor-turista. Todavia, o itinerário, marcador essencial dos ritmos e rotas da viagem, não se organiza no vazio, antes representa o elo entre o real observado, o narrado e o revisitado. Daí que parte das 
transformações que se assistiram em Portugal entre 1950 e o ano 2000 fossem percetíveis nos diversos relatos e na estruturação dos itinerários.

Também é importante realçar que os itinerários propostos nos livros de viagens analisados vão, ao longo dos 50 anos em apreço, alterando a sua rede, verificando-se uma simplificação da teia construída e a deslocação do seu centro para o Litoral e Sul. Estas constatações vão ao encontro do desenvolvimento do país na segunda metade do século XX, que logrou consolidar a centenária concentração da atividade na costa e nas cidades que a pontuam, assistindo-se à desertificação do interior e dos aglomerados populacionais mais reduzidos. Por outro lado, tal alteração nos itinerários demonstra também as transmutações dos espaços turísticos nacionais com o desenvolvimento dos destinos mais ao Sul (Brito, 2003).

Importa salientar que os itinerários turísticos que foram sendo construídos a partir de meados do século passado espelham a imagem de Portugal que foi arquitetada pelo Estado Novo. Como realça Vera Marques Alves (2007: 63), o objetivo de António Ferro era fazer emergir uma nação "detentora de uma série de signos distintivos que relevariam uma identidade única" que seria consumida interna externamente. $\mathrm{O}$ turismo externo fazia também parte deste esquema, mas assumia-se mais como um meio do que um fim. Isto é, não era necessário elaborar uma codificação do real para consumo turístico estrangeiro, os viajantes alimentar-se-iam das imagens pré-elaboradas para um público mais lato.

Por esta ótica de análise, os itinerários turísticos seguem uma lógica construtiva, sobretudo durante o período de vigência do Estado Novo, que mimetiza o arquétipo de representação nacional que foi elaborado pelo Governo de Salazar e que pressupunha a diversificação imagética das províncias numa lógica de subordinação ao todo. A estetização do país construiu objetos de culto a partir de uma fundamentação etnográfica, permitindo o reforço da identificação do povo por recurso a um jogo de identidade-alteridade (Alves, 2007).

Este binómio facilitou a representação de Portugal como um país múltiplo, mas unificado em torno de um conjunto de atributos unificadores que, curiosamente, se fundamentavam, frequentamente, na diversidade, como era o caso das danças e trajes folclóricos. 
Assim, a generalidade dos itinerários turísticos que analisámos foram moldados em torno deste arquétipo imagético que, apesar de ser uma construção salazarista, consolidou-se e propagou-se para lá do fim do regime.

Contudo, apesar de Portugal, durante os 50 anos em estudo, ter alterado profundamente as fronteiras, as limitações turísticas impostas aos livros de viagens raras vezes permitiram que Portugal fosse analisado para além da sua contingentação continental europeia, o que dececionaria, decerto, Salazar, conquanto o seu pensamento político e económico se sustentava na artificial e hipócrita concetualização da Nação como um todo e que foi representada e propagandeada num célebre cartaz que clamava que "Portugal não é um País Pequeno" (Vieira, 2010).

De resto, os condicionalismos turísticos também estarão na base das modificações operadas ao nível da perspetivação da viagem e da construção dos itinerários em território nacional, observando-se uma crescente busca do local em detrimento do percurso. Esta passagem da estética do itinerário para a estética do percurso, embora nunca colocasse em causa a existência de itinerários bastante completos nos livros de viagens, influenciará a narrativa e a hierarquização do território e dos temas.

Em suma, através da nossa investigação comprovámos que os livros de viagens produzem poderosos discursos que influenciam a prática turística e a representação que os viajantes constroem dos países. Mais, no caso Português, parte dessa representação é subsidiária de uma prévia edificação imagética construída com finalidades políticas, o que demonstra a interpenetração das esferas e a facilidade com que se corromperam os discursos britânicos sobre o nosso país.

\section{Referências bibliográficas}

Alves, V. 2007, A poesia dos simples: arte popular e nação no Estado Novo. Etnográfica, 11 (1): pp: 63-89.

BRITO, S. 2003, Notas sobre a evolução do viajar e a formação do turismo. Lisboa: Medialivros.

Culler, J. 1981, The pursuit of Signs. Ithaca: Cornell University Press. 
Drucker, P. 2002, O melhor de Peter Drucker. O Homem, A Administração, A sociedade. São Paulo: Nobel.

Fussell, P. 1980, Abroad: British Literary Traveling between the Wars. New York/ Oxford: Oxford University Press.

JAcoBs, C. 2001, Tourist Guidebooks, Local Colour and the Spiritual Churches of New Orleans. Journal of American Folklore, 114: pp. 309-330.

KnAFOU, R. 1992, L'invention du Tourisme. In A. Baillye e D. Pumain (Dir), Encyclopédie de la Géografhie. Paris: Economica, pp. 651-864.

URRY, J. 2002, The Tourist Gaze. Leisure and Travel in contemporary Societies. London: Sage.

VIEIRA, P. 2010, O Império como fetiche no Estado Novo: feitiço do império e o sortilégio colonial. Portuguese Cultural Studies, 3, Spring: pp. 126-144.

Young, T. 2005, Going by the Book: Backpacker Travellers in Aboriginal Australia and the Negotiation of Text and Experience. Tese de Doutoramento não publicada. Newcastle: University of Newcastle.

\section{Fontes Primárias}

Appleton, T. e Ferguson, G. 1972, Portugal, Letts Holiday Guides. London/Edinburgh/New York: Charles Letts \& Company Limited.

Blake, W. 1963, Portuguese Journey. London: Alvin Redman.

Bridges, A. e Lowndes, S. 1958, The Selective Traveller in Portugal. London: Chatto \& Windus.

Clyne, D. 1965, Your guide to Portugal.Londres: Alvin Redman.

Cooper, G. 1952, Your Holiday in Spain and Portugal. London: Alvin Redman.

Hogg. A.1987, Traveller's Portugal. London: Solo Mio Books.

Hogg, G. 1954, Portuguese Journey. London: Museum Press.

Hyland, P. 1996, Backwards out in the big world - A voyage into Portugal. London: Harper Collins Publishers.

Lowndes, S. 1987, Portugal, A Travellers' Guide. London: Thornton Cox.

MYHill, H. 1972, Portugal. London: Faber \& Faber.

Salter, C. 1964, A Fortnight in Portugal. Londres: Percival Marshal.

Salter, C. 1970, Portugal. London: B. T. Batsford Ltd. 
Timmons, N. 1992, Off the beaten track, Portugal. London: Moorland Publishing. Londres.

Waite, J. 1985, Mean Feat - A 3,000 - mile walk through Portugal, Spain, France, Switzerland and Italy. London: The Oxford Illustrated Press.

Wood, K. e McDonald, G. 1990, Holiday Portugal. London: Fontana Collins. 
Mapa 1 - Itinerários de The Selective Traveller in Portugal (1958)

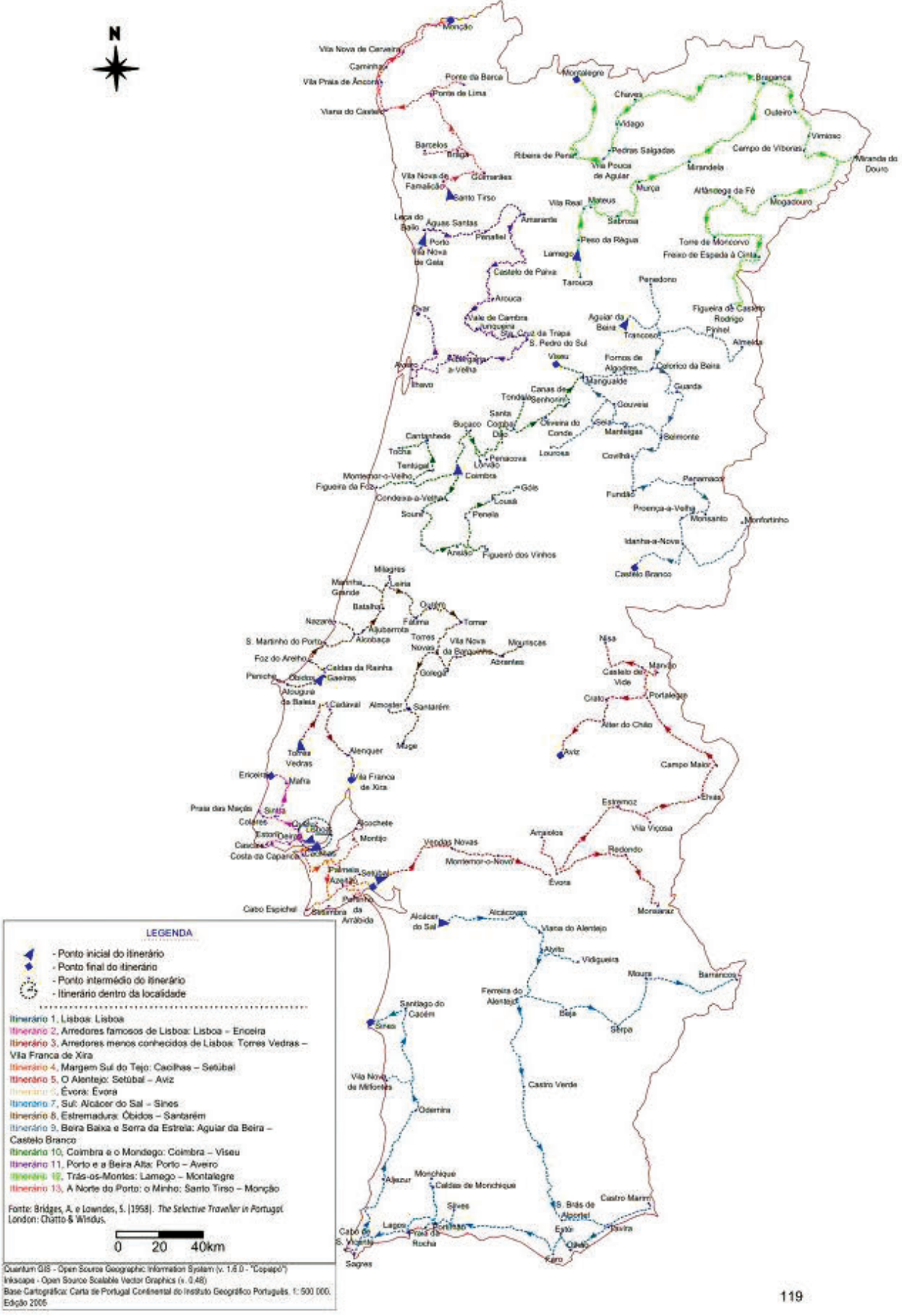


Mapa 2 - Itinerários de Portuguese Journey (1954)

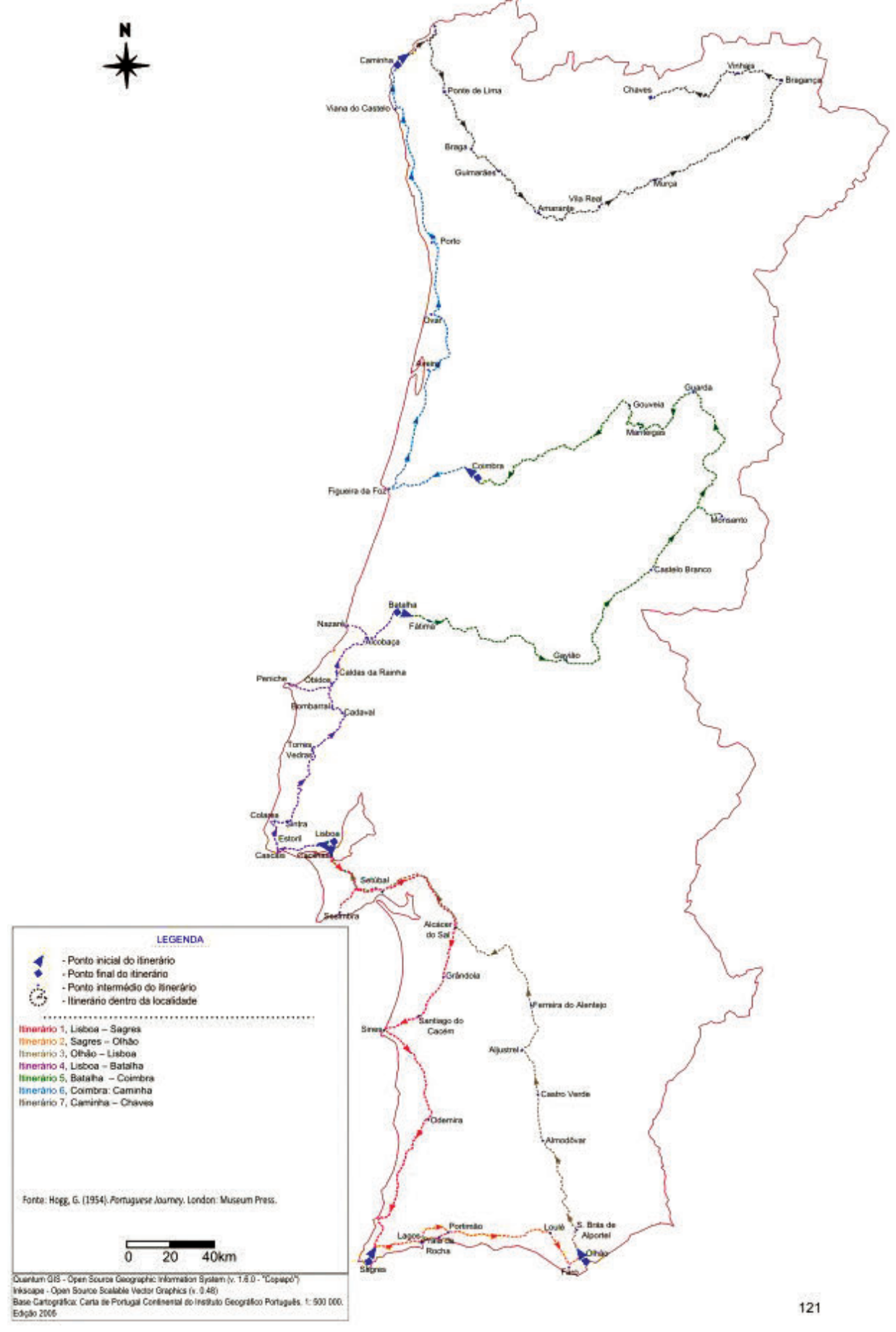


Mapa 3 - Itinerários de Your Hollday in Spain and Portugar (1952).

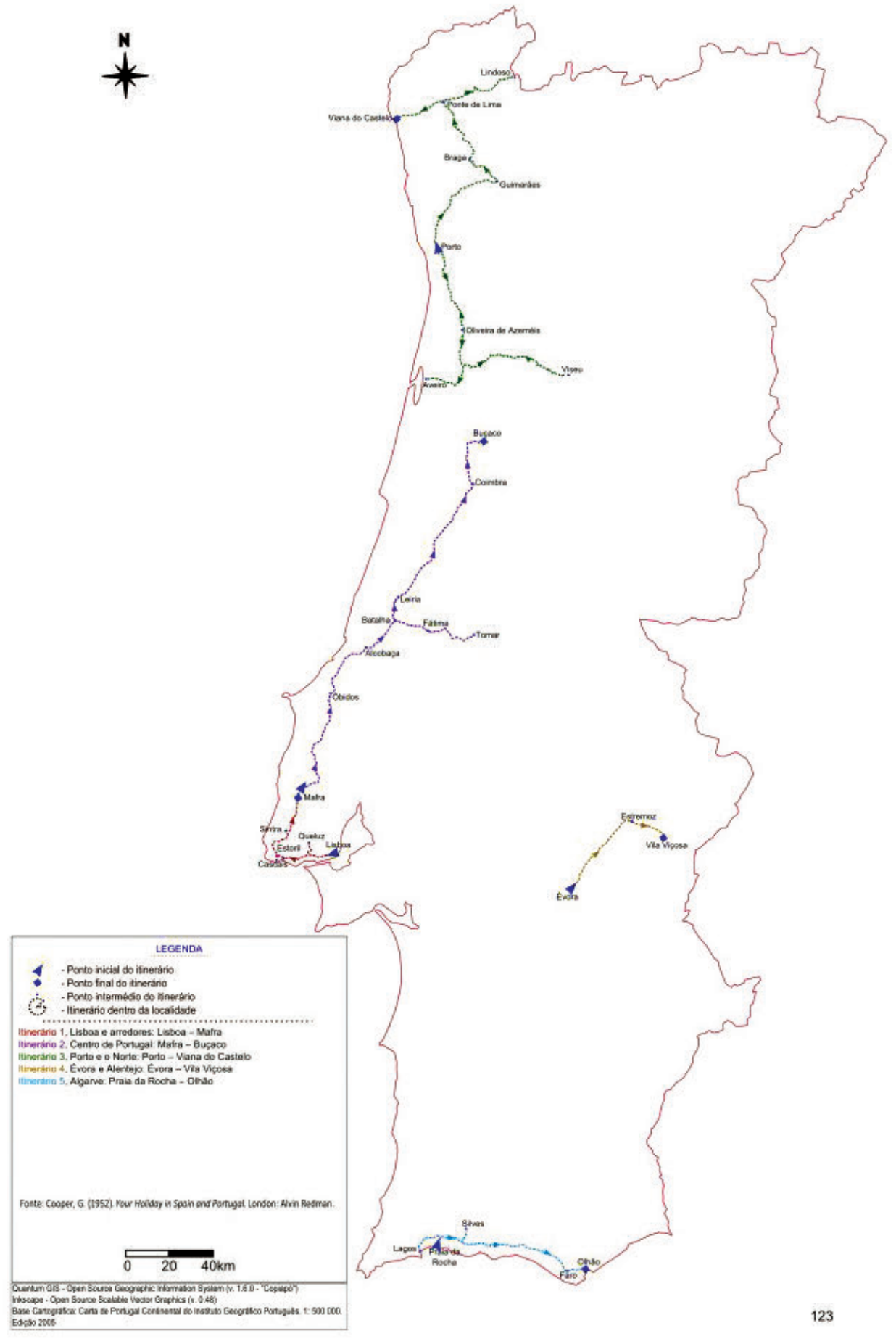


Mapa 4 - Itinerários de Portuguese Journey de Blake, W. (1963).

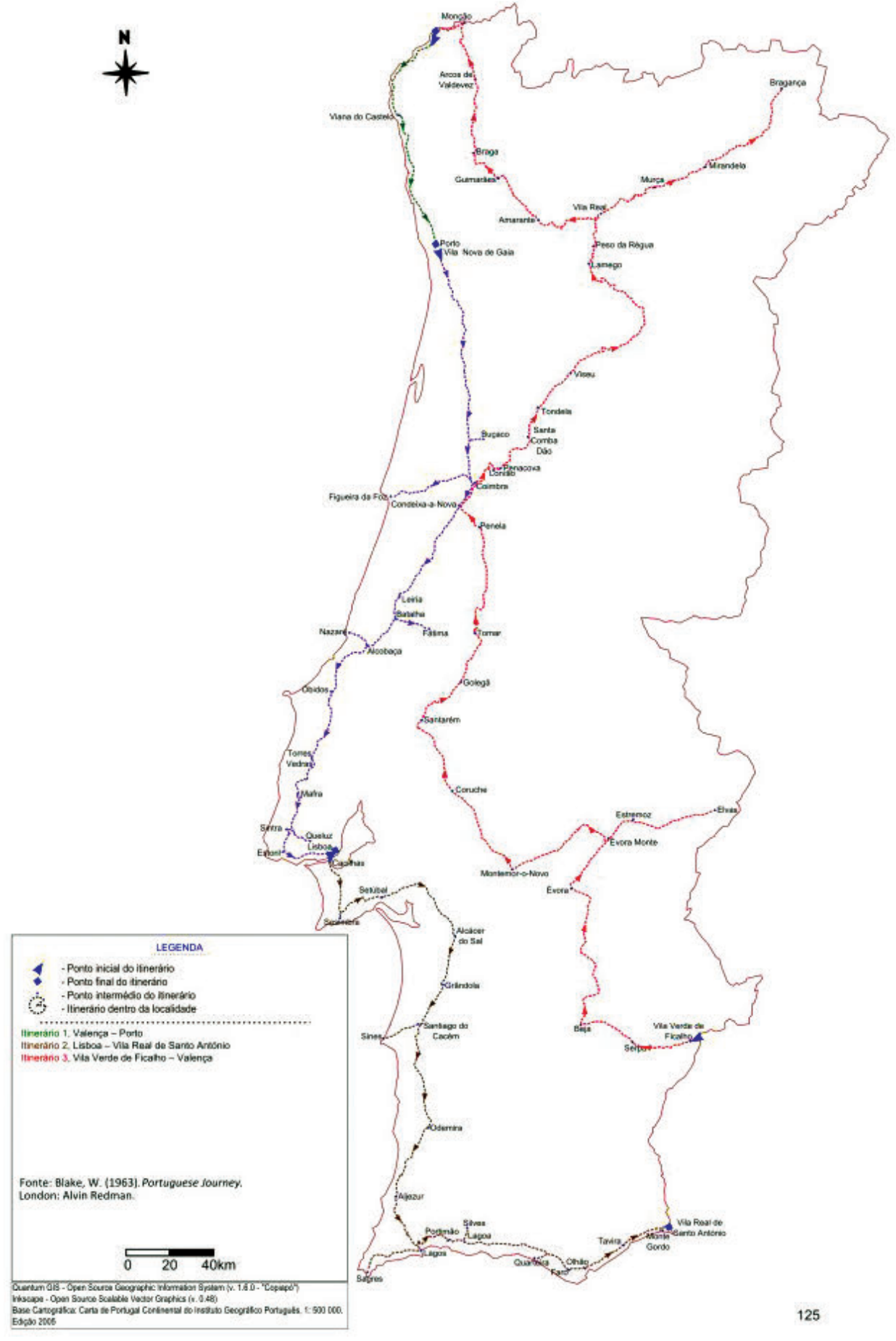


Mapa 5 - Itinerários de A fortnight in Portugal (1964).

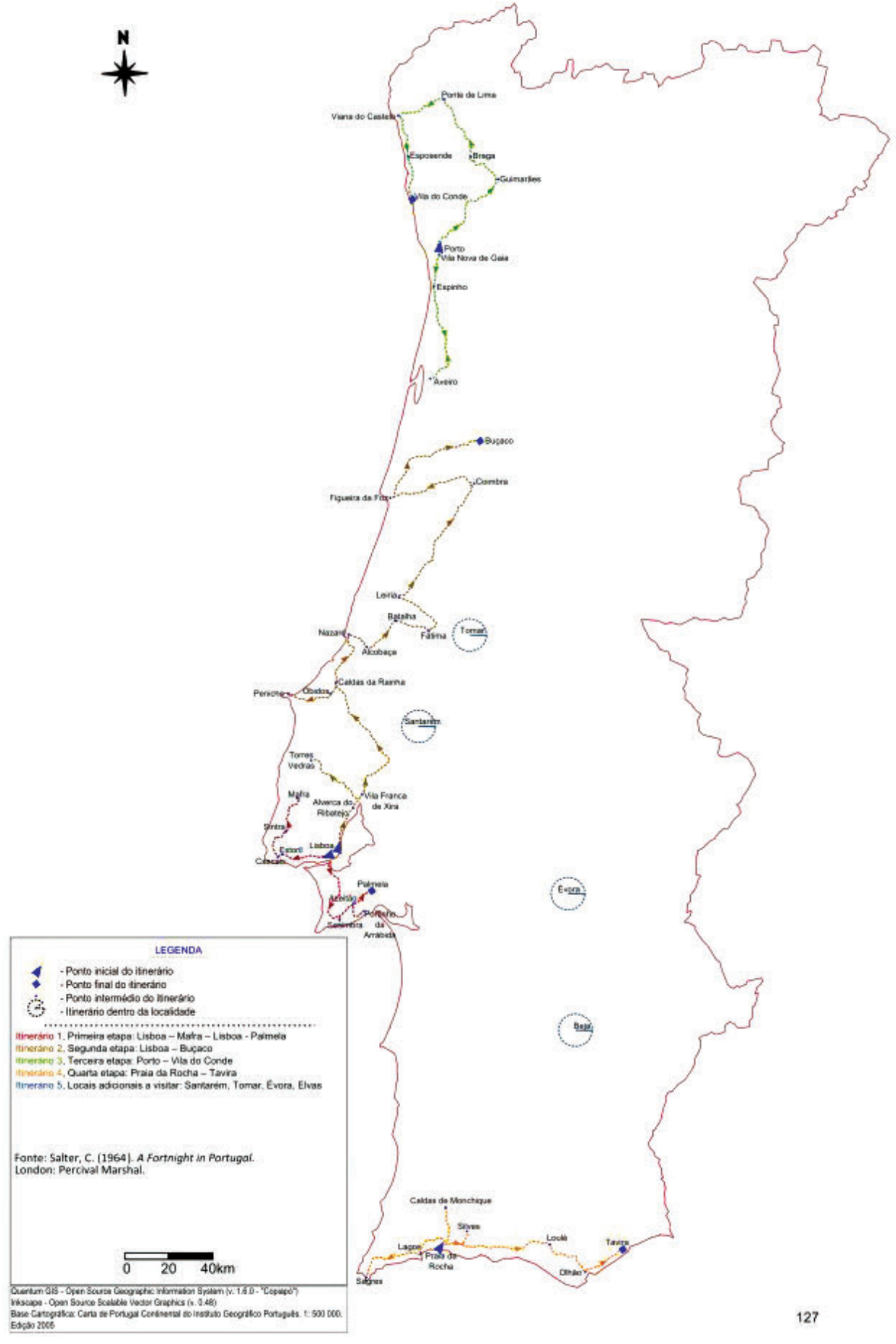


Mapa 6 - Itinerários de Your guide to Portugal (1965)

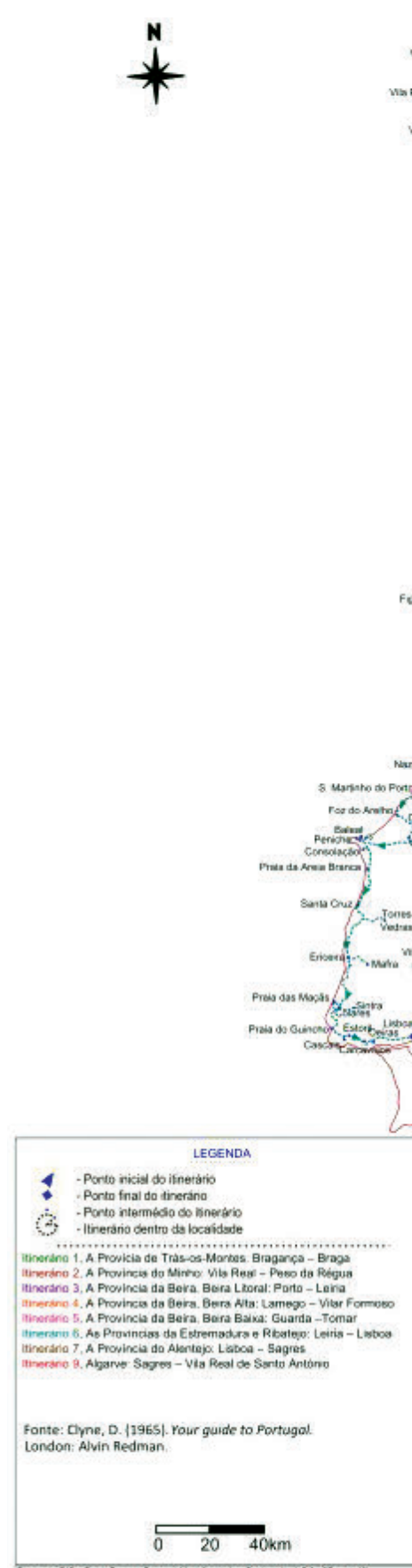

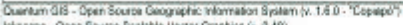

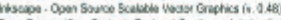

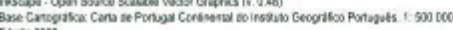
Etasso 2006
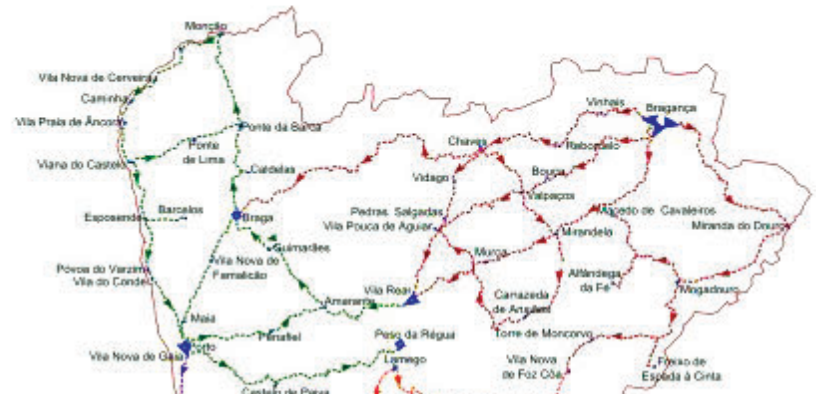

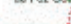
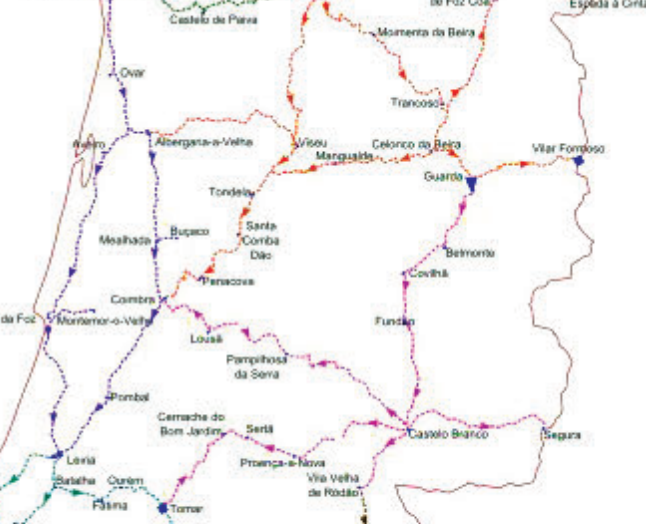

rícobass

? Ro usiax
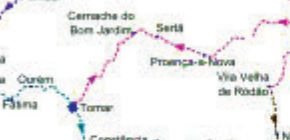

wo vets
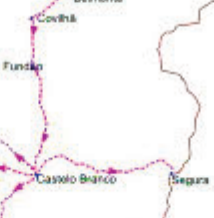
Mapa 7 - Itinerários de Portugal, Letts Holiday Guides (1972).

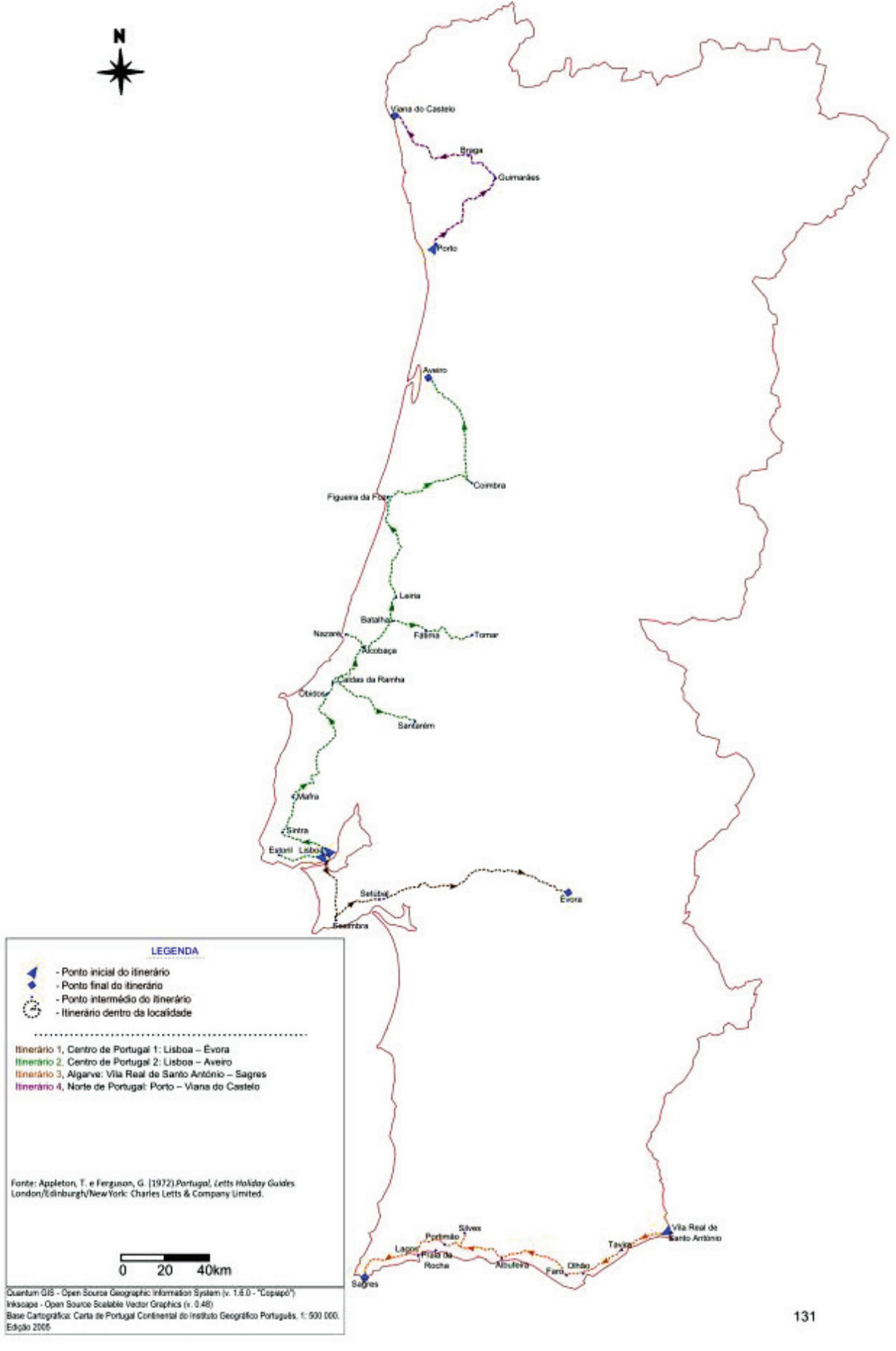


Mapa 8 - Itinerários de Portugal (1970).

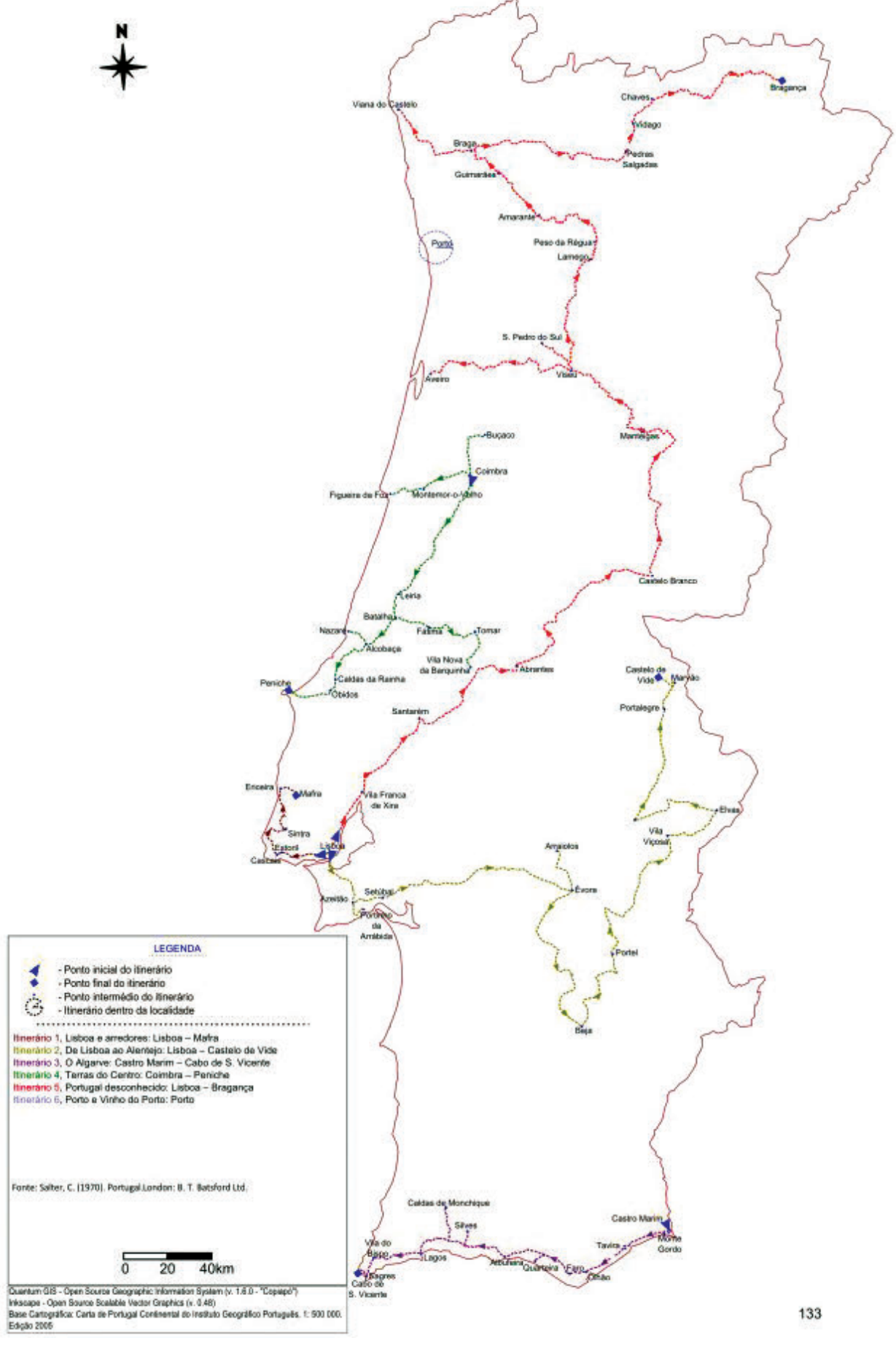


Mapa 9 - Itinerários de Portugal (1972).

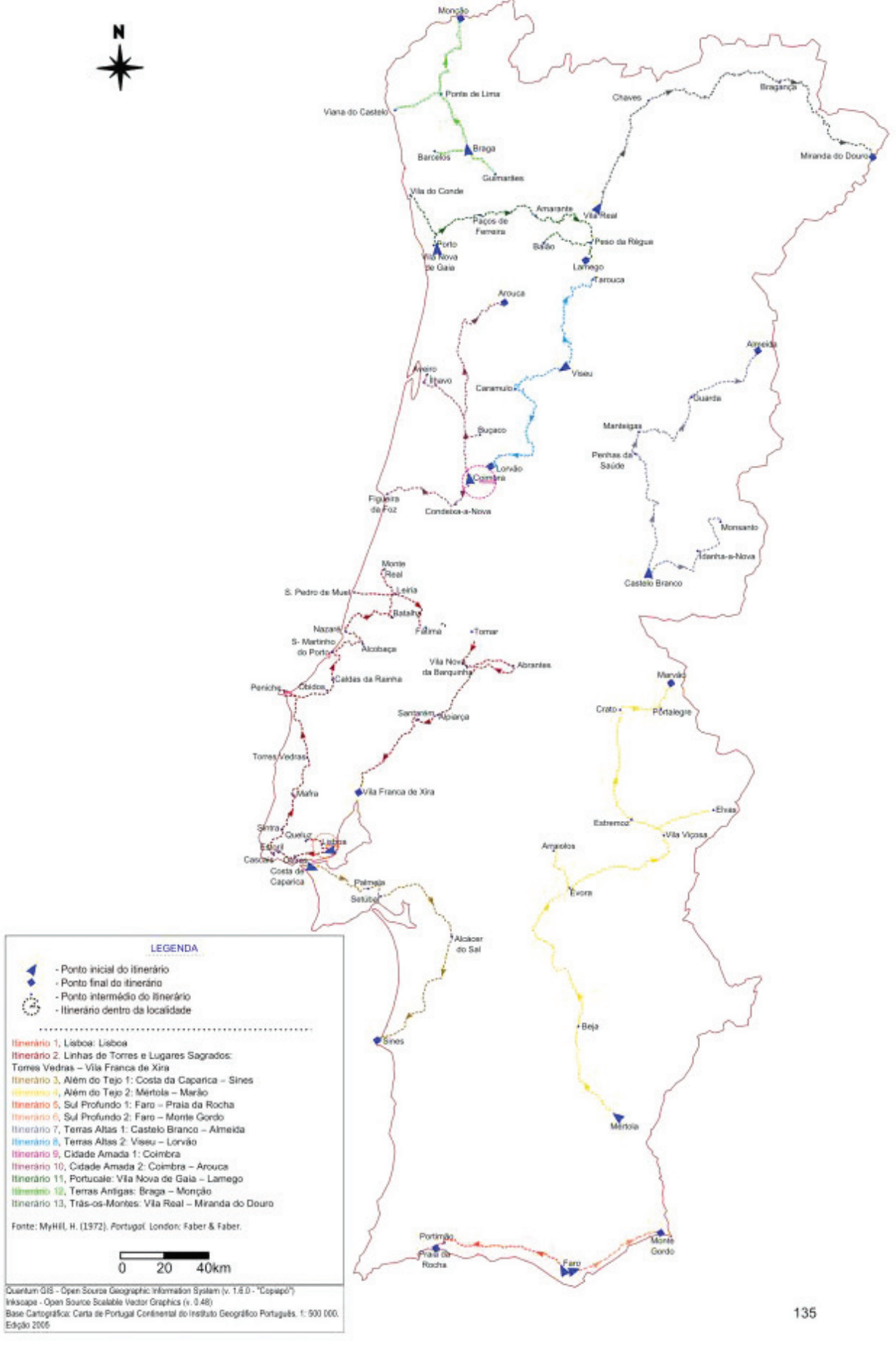


Mapa 10 - Itinerários de Traveller's Portugal (1987).

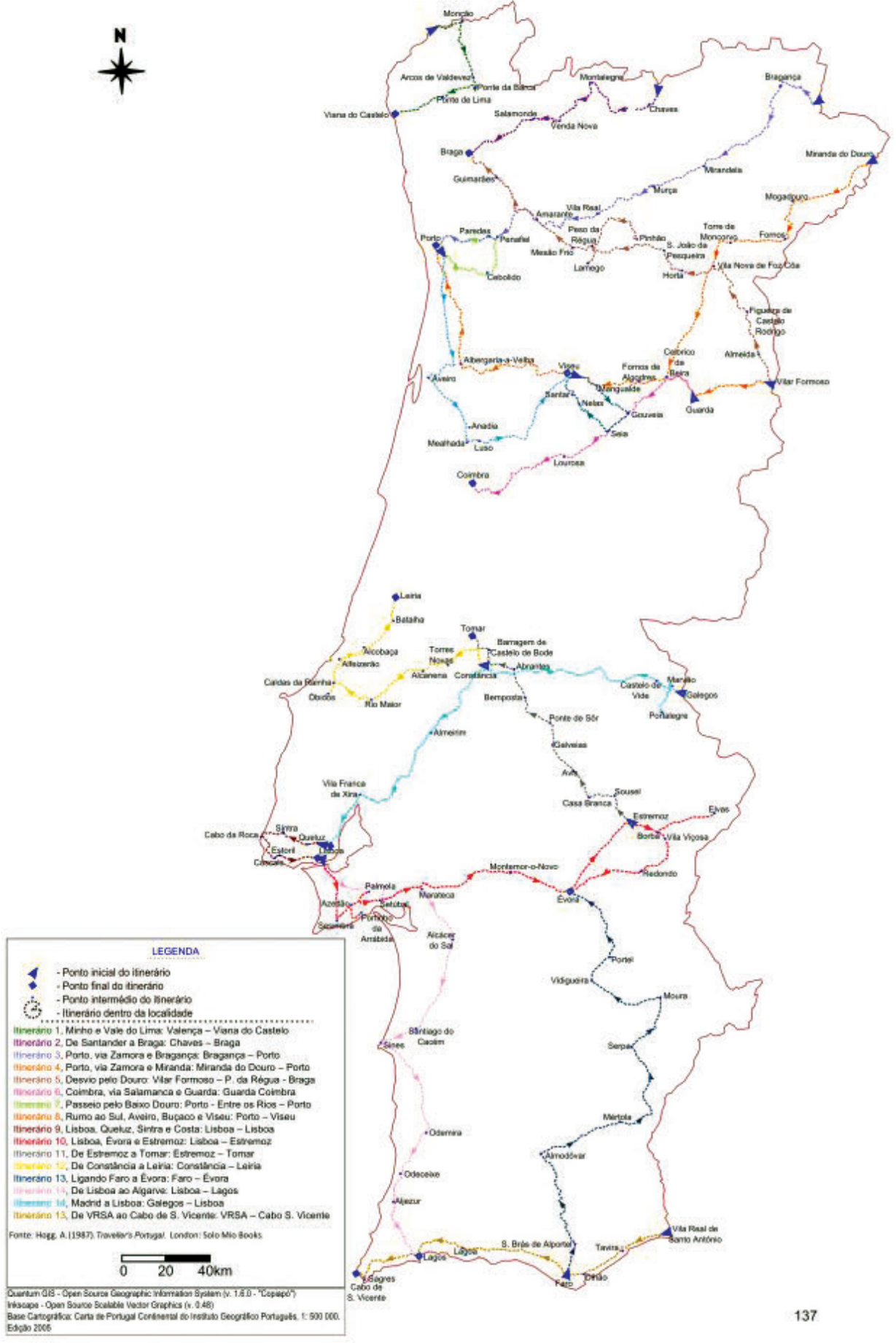


Mapa 11 - Itinerários de Mean Feat.. (1985).

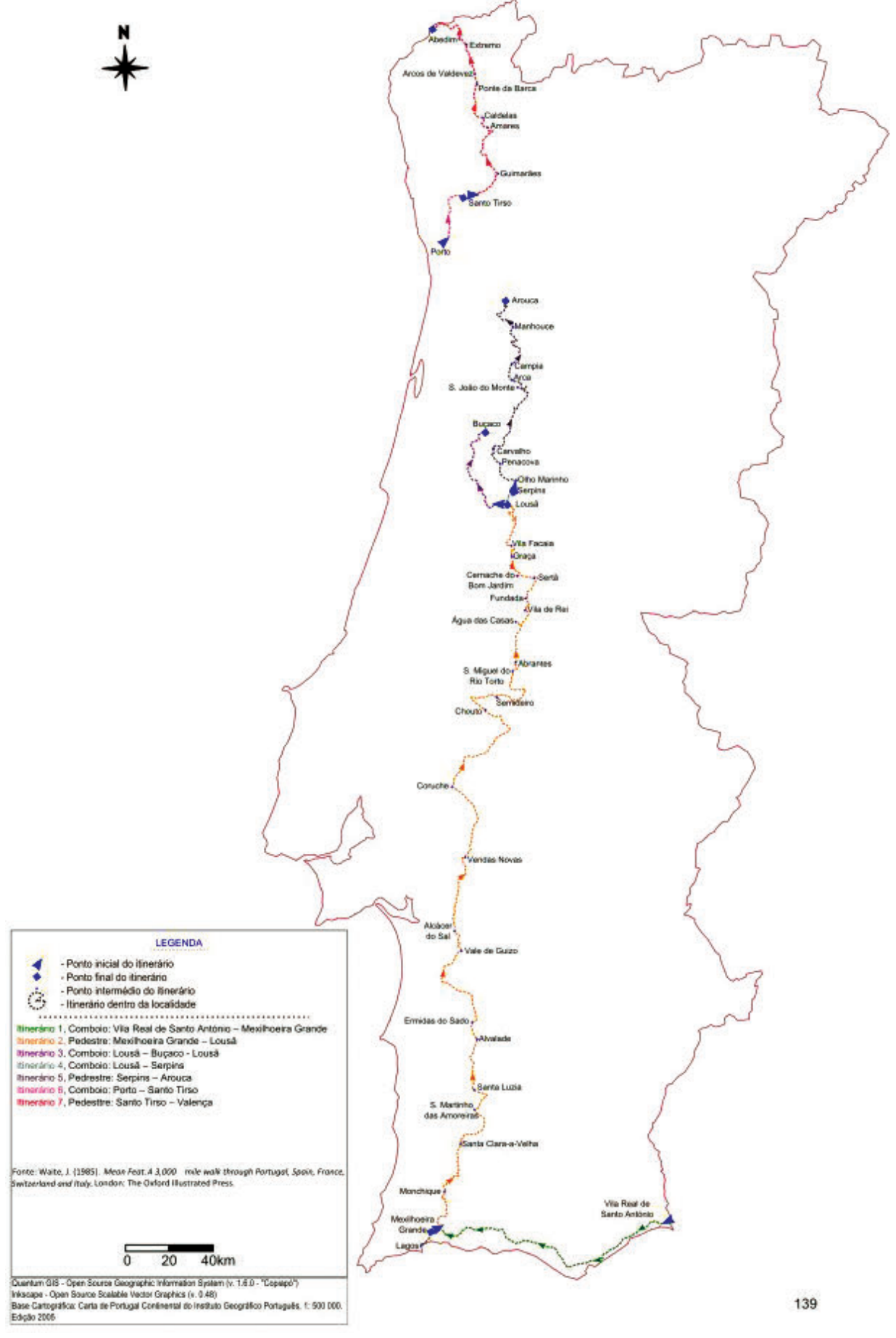


Mapa 12 - Itinerários de Travellers' Guide (1987).

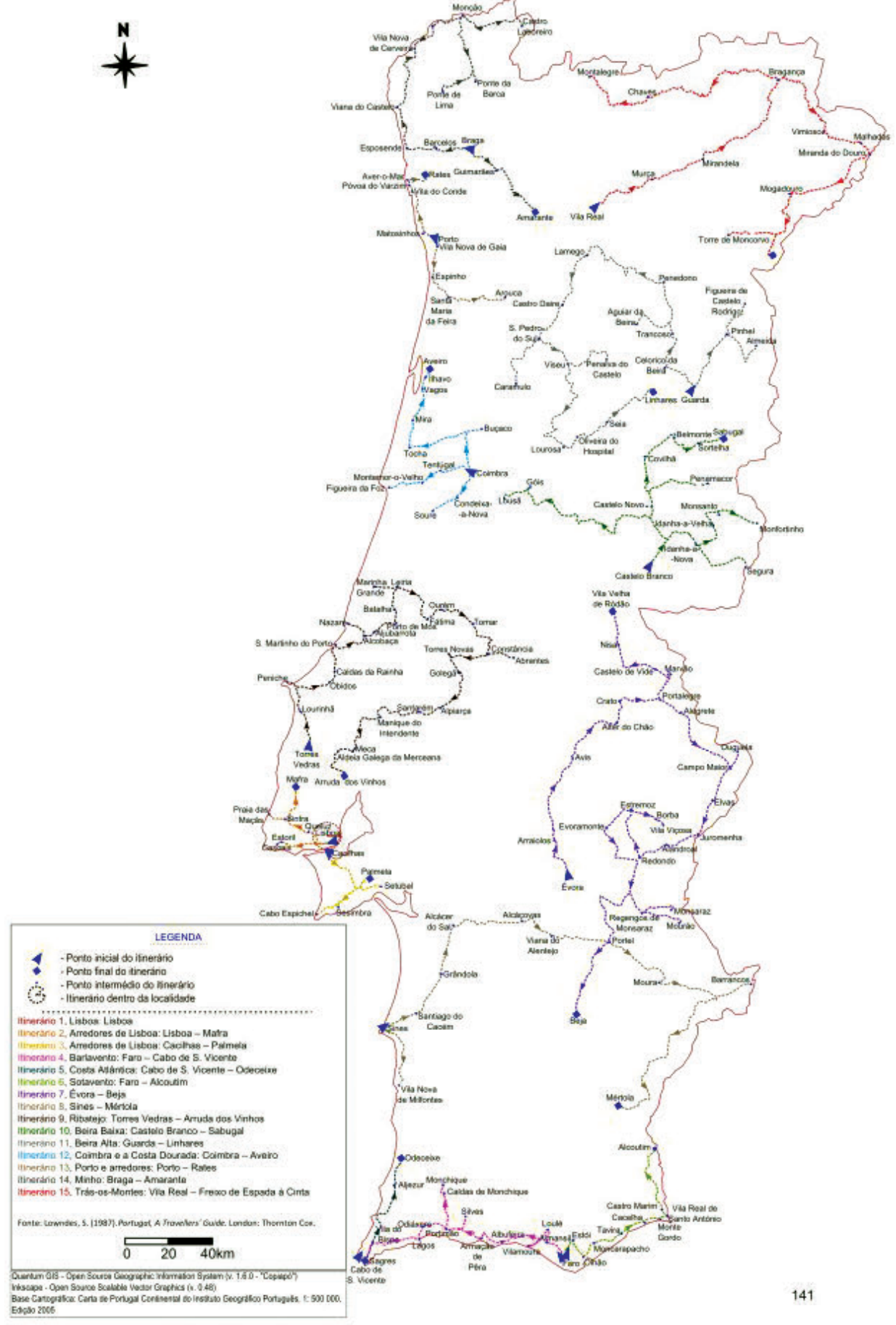


Mapa 13 - Itinerários de Off the beaten track, Portugal (1992).

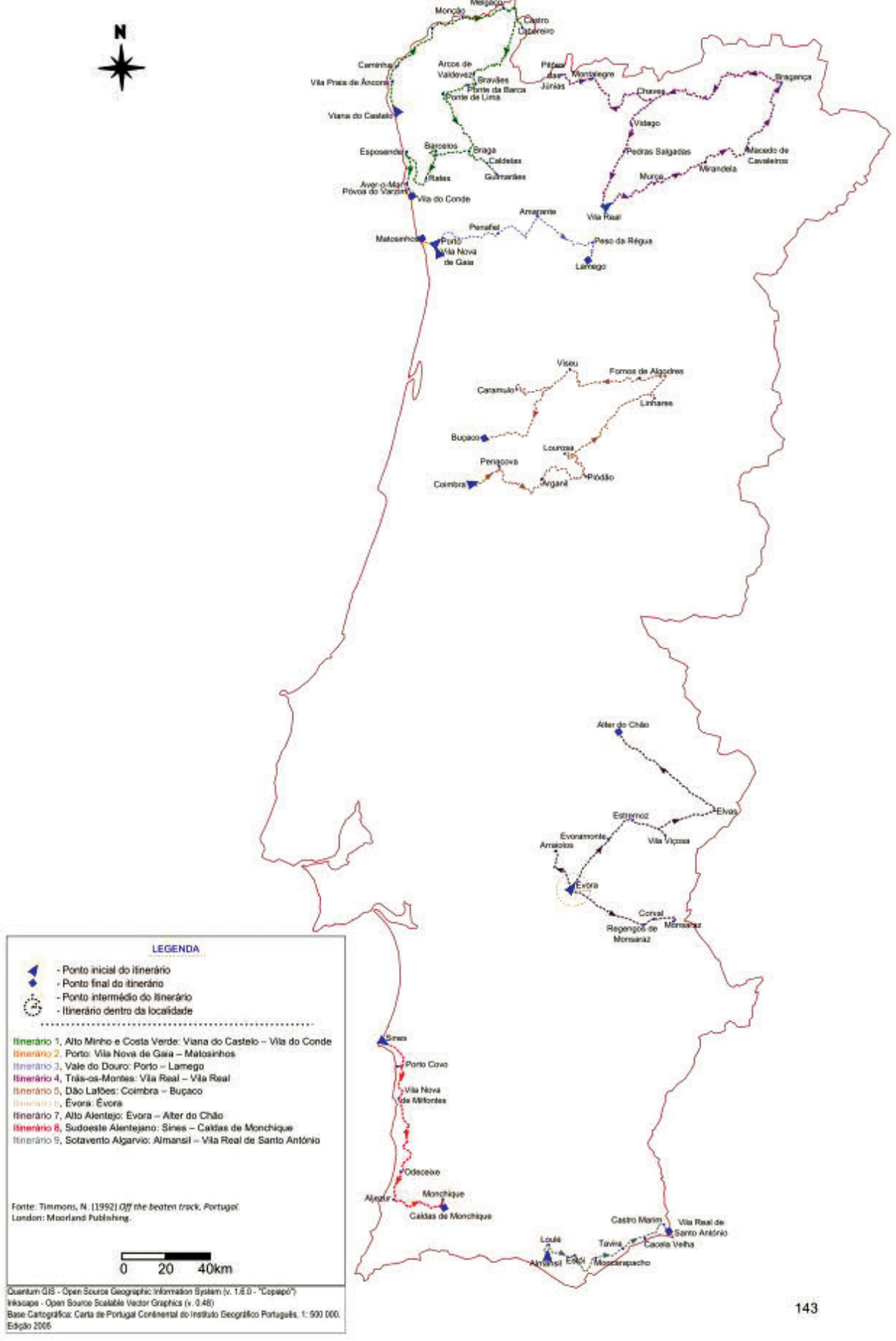


Mapa 14 - Itinerários de Backwards out in the big world - A voyage into Portugal (1996).

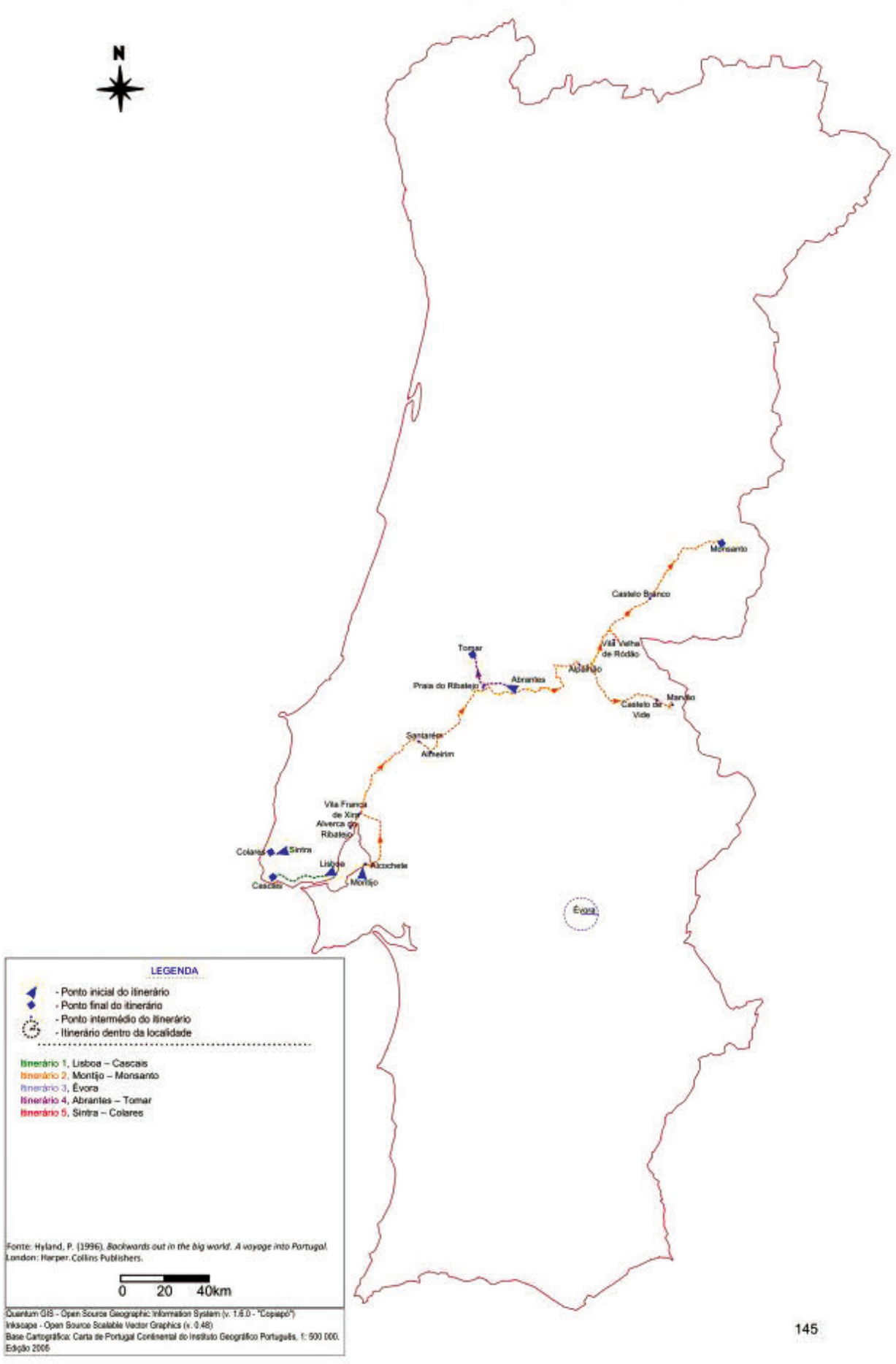


Mapa 15 - Itinerários de Holiday Portugal (1990)

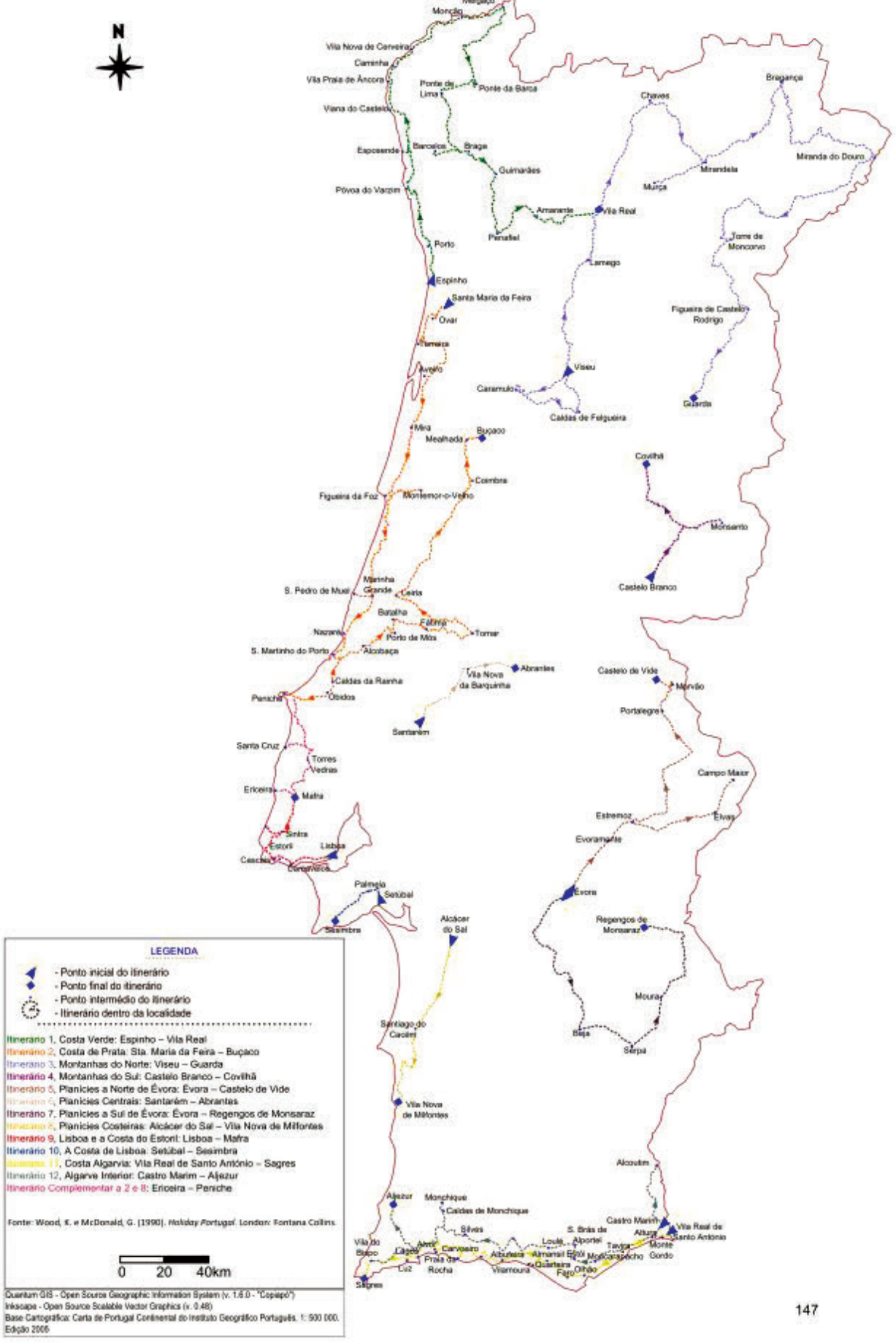


Mapa 16 - Eixos e núcleos principais dos itinerárics analisados entre 1950 e 2000.
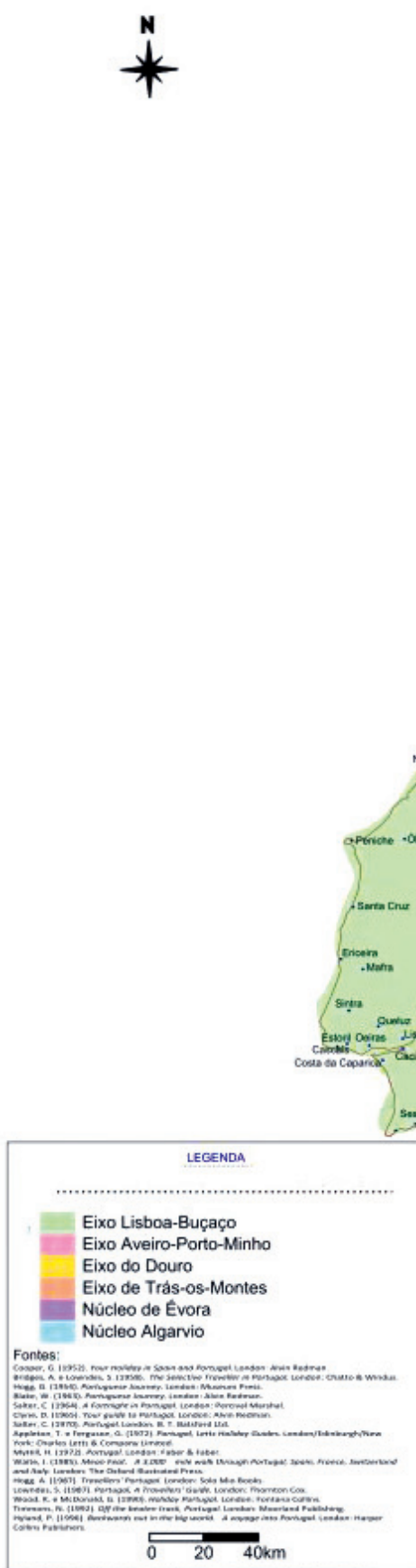

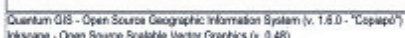

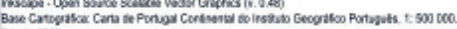
Edpo 2006

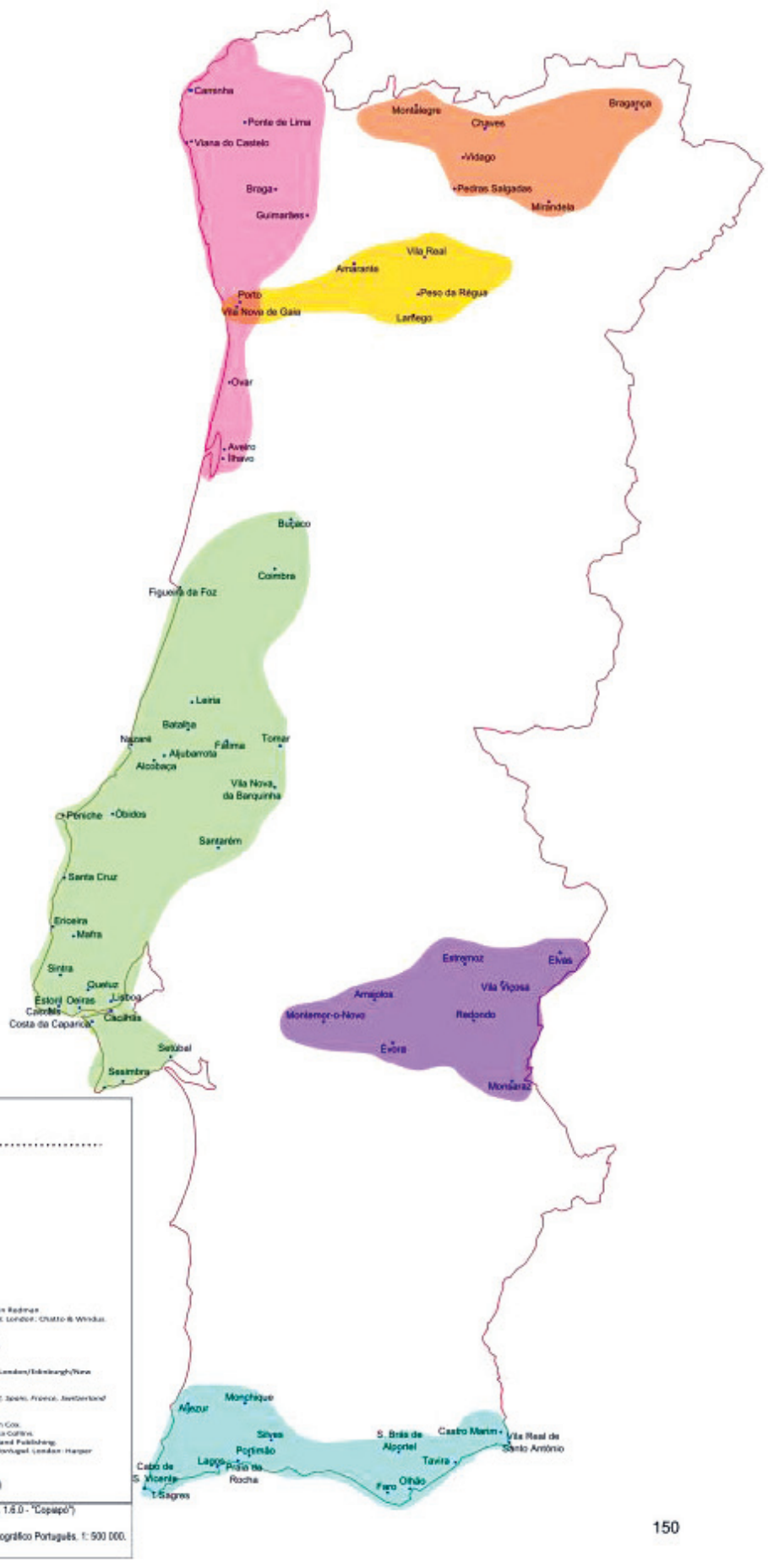

